\title{
$\mathrm{CO}_{2}$ 지중저장 시 단층 안정성 평가 \\ 김현우, 천대성, 최병희, 최헌수, 박의섭*
}

\section{Case Study on Stability Assessment of Pre-existing Fault at $\mathrm{CO}_{2}$ Geologic Storage}

\author{
Hyunwoo Kim, Dae-Sung Cheon, Byung-Hee Choi, Hun-Soo Choi, Eui-Seob Park*
}

\begin{abstract}
Increase of pore fluid pressure resulting from injection of $\mathrm{CO}_{2}$ may reactivate pre-existing faults, and the induced seismic activities can raise the safety issues such as seal integrity, restoration of storage capacity, and, in the worst case, removal of previously injected $\mathrm{CO}_{2}$. Thus, fault stability and potential for $\mathrm{CO}_{2}$ leakage need to be assessed at the stage of site selection and planning of injection pressure, based on the results of large-scale site investigations and numerical modeling for various scenarios. In this report, studies on the assessment of fault stability during injection of $\mathrm{CO}_{2}$ were reviewed. The seismic activities associated with an artificial injection of fluids or a release of naturally trapped high-pressure fluids were first examined, and then site investigation methods for the magnitude and orientation of in situ stresses, the distribution and change of pore fluid pressure, and the location of faults were generally summarized. Recent research cases on possibility estimation of fault reactivation, prediction of seismic magnitude, and modeling of $\mathrm{CO}_{2}$ leakage through a reactivated fault were presented.
\end{abstract}

Key words $\mathrm{CO}_{2}$ storage, fault reactivation, stability assessment, case study, modeling

초 록 $\mathrm{CO}_{2}$ 를 지중저장하는 과정에서 유체압력의 증가로 인한 단층 활성화는 저장영역의 기밀성 유지에 중대한 영향을 미치며, 상황에 따라 저장기능의 회복 또는 저장중인 $\mathrm{CO}_{2}$ 의 처리 문제 등으로 확대될 수 있다. 따라서 현지조사 결과의 불확실성을 최소화하고 이를 토대로 부지 선정과 주입압력 결정 단계에서 실제 조건에 가까운 모델링을 수행하여 저장영역 내 단층의 안정성과 $\mathrm{CO}_{2}$ 누출 가능성을 평가하여야 한다. 본 연구에서는 이와 관련된 기존 연구 결과들을 살펴봄으로써 연구 동향 및 연구 방법에 대한 정보를 제공하고자 하였다. 먼저 인위 적으로 지반에 주입된 유체 또는 자연 생성되어 응집되어 있던 $\mathrm{CO}_{2}$ 에 의해 지진활동이 일어났던 사례들을 조사 하였으며, 현지응력의 크기 및 방향, 단층 및 유체압력 분포 자료를 획득하는 방법에 대해 살펴보았다. 그리고 단층 활성화 가능성 평가 및 지진활동 시 진동 크기 추정, 활성화에 따른 $\mathrm{CO}_{2}$ 누출 모델링 관련 연구 사례를 정리하였다.

핵심어 $\mathrm{CO}_{2}$ 지중저장, 단층 활성화, 안정성 평가, 사례 연구, 모델링

\section{1. 서 론}

Zoback \& Gorelick(2012)은 미국 국립과학원회보 게

Received: Jan. 25, 2013

Revised: Feb. 18, 2013

Accepted: Feb. 19, 2013

*Corresponding Author: Eui-Seob Park

Tel) +82428683098, Fax) +82428683416

E-Mail) espark@kigam.re.kr

KIGAM, 124 Gwahang-no, Yuseong-gu, Daejeon 305-350, Korea
재 논문에서 대규모 $\mathrm{CO}_{2}$ 지중저장으로 인한 지진 발생 가능성에 대해 논의하였다. 논문에 따르면 단순히 미국 과 아시아에서의 과거 지진 발생 위치만을 확인하더라 도 판의 경계뿐만 아니라 대륙 내부에서도 리히터 규모 $M_{L} 7$ 이상의 큰 지진이 때때로 일어났음을 알 수 있으 며, 이처럼 산재된 단층대 가운데 대규모 단층은 부지 선정 단계에서 피할 수 있으나 국부적인 소규모 단층까 지 완벽하게 배제하기는 어렵다. 또한 증가하는 $\mathrm{CO}_{2}$ 처 리 요구량에 맞춰 저장영역이 커질수록 발견되지 않은 단층대가 포함될 가능성은 높아진다. 특히 이러한 단층 
이 응력조건의 작은 변화에도 미끄러지는 임계응력 (critically stressed) 상태에 있다면 $\mathrm{CO}_{2}$ 의 지중 주입으 로 인한 간극유압(pore fluid pressure) 증가는 지진 발 생의 주원인이 될 수 있다. 이때 보통 규모의 지진이 지 하 심부 주입위치 부근에서 일어난다면 지표면에 미치 는 영향은 크지 않지만 저장영역의 건전성(integrity)에 미치는 영향은 상당할 수 있다. 따라서 지진활동(seismic activity)이 일어났다면 저장영역의 기밀성이 유지되고 있는지 확인해야 하며, 기밀성에 문제가 있는 경우 이 미 주입된 $\mathrm{CO}_{2}$ 의 처리 방안은 중요 과제가 된다. 국내 에서도 최근 $\mathrm{CO}_{2}$ 지중저장 관련 기술 및 해외 동향 분 석(Kim et al., 2008; Chae et al., 2010)을 거쳐 육상 $\mathrm{CO}_{2}$ 지중저장 파일럿 저장소 선정 연구(교육과학기술 부), $\mathrm{CO}_{2}$ 해양지중저장기술개발사업(국토해양부) 등 $\mathrm{CO}_{2}$ 의 지중저장과 관련된 연구가 활발히 수행되고 있 다. 특히 여러 연구 주제 중에서도 시추정을 통한 $\mathrm{CO}_{2}$ 의 누출 가능성, 덮개암(cap rock)의 안정성, 단층 활성 화 여부 및 누출 가능성 등 저장영역의 기밀성 확보와 관련된 분야는 부지 선정에서부터 모니터링 계획까지 전 과정에 걸쳐 핵심요소로 다루어지고 있다(Park et al., 2012).

이에 본 연구에서는 $\mathrm{CO}_{2}$ 의 지중 주입 시 기존 단층의 안정성 평가와 관련된 연구 결과들을 살펴봄으로써 연 구 동향과 연구 방법에 대한 정보를 제공하고자 하였다. 먼저 인위적으로 지반에 주입된 유체 또는 자연 생성되 어 응집되어 있던 $\mathrm{CO}_{2}$ 에 의해 지진활동이 유발되었던 사례들을 조사하였으며, 단층 안정성 평가에 필수적 정 보인 현지응력의 크기 및 방향, 단층 분포, 유체압력 분 포 및 변화 관련 자료를 획득하는 방법에 대해 개략적 으로 살펴보았다. 그리고 단층 활성화 가능성, 지진활동 시 진동 크기 추정, 활성화에 따른 $\mathrm{CO}_{2}$ 누출 모델링에 관련된 기존 연구 사례를 간략하게 정리하였다.

\section{2. 지중 유체에 의한 지진활동 발생 사례}

\section{1 유체 주입에 의한 지진활동}

폐기물의 지중처분, 지열 발전, 천연가스 지하저장, 원유의 2 차 회수 등을 목적으로 심부 시추공을 통해 유 체를 지중 주입하는 과정에서 지진활동이 일어났던 사 례는 세계 여러 곳에서 찾을 수 있다(Table 1). 이 사례

Table 1. Cases of induced seismic activity (Nicholson \& Wesson, 1990; Sminchak \& Gupta, 2003)

\begin{tabular}{|c|c|c|c|c|c|c|c|}
\hline \multirow[t]{2}{*}{ Location } & \multirow[t]{2}{*}{ Type } & Depth & $\begin{array}{l}\text { Injection } \\
\text { pressure }\end{array}$ & $\mathrm{S}_{\mathrm{h}}$ & $\mathrm{S}_{\mathrm{H}}$ & $\mathrm{S}_{\mathrm{v}}$ & \multirow{2}{*}{$\begin{array}{l}\text { Maximum } \\
\text { earthquake } \\
\text { magnitude }\end{array}$} \\
\hline & & (m) & (MPa) & $(\mathrm{MPa})$ & $(\mathrm{MPa})$ & $(\mathrm{MPa})$ & \\
\hline Denver, Colorado & waste disposal & 3,671 & 7.6 & 36.2 & $<83.0$ & 83.0 & 5.5 \\
\hline Fenton Hill, New Mexico & geothermal & 2,700 & 20.0 & 40.5 & $<63.5$ & 63.5 & $<1.0$ \\
\hline Matsushiro, Japan & research & 1,800 & 5.0 & - & - & 46.0 & 2.8 \\
\hline Dale, New York & solution mining & 426 & 5.5 & 7.6 & $>10.9$ & 10.9 & 1.0 \\
\hline Germigny, France & gas storage & 750 & $<3$ & - & - & - & $<1.0$ \\
\hline Cogdell, Texas & secondary recovery & 2,071 & 19.9 & - & - & 47.6 & 4.6 \\
\hline Rangely, Colorado & secondary/research & 1,900 & 8.3 & 31.4 & 55.2 & 42.7 & 3.1 \\
\hline Gobles field, Ontario & secondary recovery & 884 & - & - & - & 22.5 & 2.8 \\
\hline Sleepy Hollow, Nebraska & secondary recovery & 1,150 & 5.6 & - & $<26.5$ & 26.5 & 2.9 \\
\hline Sinpe Lake, Alberta & secondary recovery & - & - & - & - & - & 5.1 \\
\hline Dollarhide, Texas & secondary recovery & 2,590 & 13.8 & - & - & 59.6 & $\sim 3.5$ \\
\hline Dora Roberts, Texas & secondary recovery & 3,661 & 43.1 & - & - & 84.2 & $\sim 3.0$ \\
\hline Kermit field, Texas & secondary recovery & 1,829 & 22.1 & - & - & 42.1 & $\sim 4.0$ \\
\hline Keystone field I, Texas & secondary recovery & 975 & 10.3 & - & - & 22.4 & $\sim 3.5$ \\
\hline Keystone field II, Texas & secondary recovery & 2,987 & 17.6 & - & - & 68.7 & $\sim 3.5$ \\
\hline Monahans, Texas & secondary recovery & 2,530 & 20.7 & - & - & 58.2 & $\sim 3.0$ \\
\hline Ward-Estes field, Texas & secondary recovery & 914 & 11.7 & - & - & 21.0 & $\sim 3.5$ \\
\hline Ward-South, Texas & secondary recovery & 741 & 13.8 & - & - & 17.0 & $\sim 3.0$ \\
\hline
\end{tabular}

Note) $\mathrm{S}_{\mathrm{h}}, \mathrm{S}_{\mathrm{H}}$, minimum \& maximum horizontal principal stress; $\mathrm{S}_{\mathrm{v}}$, vertical stress. 
들은 공통적으로 다음 세 가지 특징을 보이는데 주입위 치와 지진활동 영역이 지리적으로 매우 근접해 있었고, 현지응력과 주입압력을 토대로 응력상태를 조사해보면 대부분 기존 불연속면을 따라 미끄러짐이 일어날 수 있 는 이론적 임계값을 초과하였다. 또한 지중 주입으로 유발된 지진활동은 대개 짧은 시간 동안 소규모 진동이 다수 발생하는 특징을 보였으며, 이러한 특징은 자연발생 적인 지진활동과 명확히 구분되는 것이었다(Nicholson \& Wesson, 1990).

지중 주입 목적별로 대표적인 지진활동 유발 사례를 살펴보면, 콜로라도 덴버 인근 Rocky Mountain Arsenal 사례는 폐기물을 지중처분하는 동안 진동이 유발된 경 우로 주입정은 평평한 퇴적암층을 지나 심하게 파쇄된 편마암층까지 굴착(심도 $3,671 \mathrm{~m}$ )되었으며, 1962년 화 학 제조과정 중 생겨난 폐기물을 지반에 주입하기 시작 하자 진동이 감지되었다(해당 지역에서 1882년에 마지 막으로 지진이 감지되었음). 초기에는 유체 주입과 지 진활동을 연결 짓지 못하고 1965 년이 되어서야 관련성 을 확인하여 이듬해 2월 주입을 중단하였으나 지진활동 은 계속되었으며, 1967년 4월과 11월 사이에는 $M_{L}$ 5-5.5 규모의 큰 진동이 세 차례 발생하기도 하였다. 조 사 결과 초기 지진활동은 주입정 바닥 부근에서 있었으 며, 이후 주입정으로부터 4-6 km 떨어진 위치까지 북서 및 남동방향으로 퍼져나간 것으로 분석되었다(Fig. 1). 중단 전까지 평균 주입률 $28.68 \mathrm{~m}^{3} / \mathrm{hr}$ 로 총 $620,000 \mathrm{~m}^{3}$ 의 유체를 주입하였으며 최대 주입압력은 $7.6 \mathrm{MPa}$ 이었 다(Nicholson \& Wesson, 1990; Sminchak \& Gupta, 2003).

뉴멕시코 Fenton Hill 지역에서는 1979년 고온암체
를 이용한 지열발전을 위해 수압파쇄를 수행하였으며, 5.5 시간 동안 약 $460 \mathrm{~m}^{3}$ 의 물이 최대 $20 \mathrm{MPa}$ 의 압력으 로 주입되었다. 이때 분당 3-4개의 미소진동이 감지되 었으나 대부분 수압파쇄로 균열이 확장되는 영역 주변 $30 \mathrm{~m}$ 이내에 국부적으로 분포하였다(Nicholson \& Wesson, 1990). 스위스 Basel에서도 고온암체를 이용한 지열발 전 과정에서 지진활동이 일어났다. 2006년 12월, 7일간 약 $11,500 \mathrm{~m}^{3}$ 의 물이 고압으로 지중 주입되는 동안 주 입정 주변에서 10,500 회 이상 진동이 감지되었다. 주입 압력과 주입률을 서서히 증가시키자 지진활동의 발생 빈도와 크기가 꾸준히 증가하였다. 주입압력 $29.6 \mathrm{MPa}$, 최대 주입률 $180 \mathrm{~m}^{3} / \mathrm{hr}$ 로 약 16 시간 동안 주입하였을 때 사전 설정된 안전한계를 초과하는 $M_{L} 2.6$ 크기의 진 동이 저류층에서 발생하여 주입을 중단하였으나 같은 날 동일 위치에서 각각 규모 $2.7,3.4$ 의 지진활동이 추가 적으로 일어났다. 이후 주입정에서 물을 배수함에 따라 지진활동은 급격히 감소하였으나 그 후로도 2년 동안 주 입정 바닥에 설치된 측정 장비에서 지반의 진동이 산발 적으로 감지되었다. 조사 결과 유체 주입이 계속되는 동 안은 지진활동이 확산과정처럼 시추공으로부터 퍼져나 갔으며, 주입 중단 후에는 수리자극된 부분(stimulated volume) 주변에서 지진활동이 집중적으로 일어났다 (Deichmann \& Giardini, 2009).

콜로라도 Rangely 유전지역에서는 원유의 2차 회수 를 위해 1958년부터 최대 $8.3 \mathrm{MPa}$ 의 압력으로 심도 약 $2 \mathrm{~km}$ 의 시추공을 통해 물을 주입하고 있었으며, 1962 년 모니터링 장비를 설치한 이후 유전지역 내에서 진동 이 지속적으로 감지되었다. 정밀조사 결과 지진활동은 길이 $4 \mathrm{~km}$, 폭 $1.5 \mathrm{~km}$ 의 길고 좁은 지역에서 주로 감지

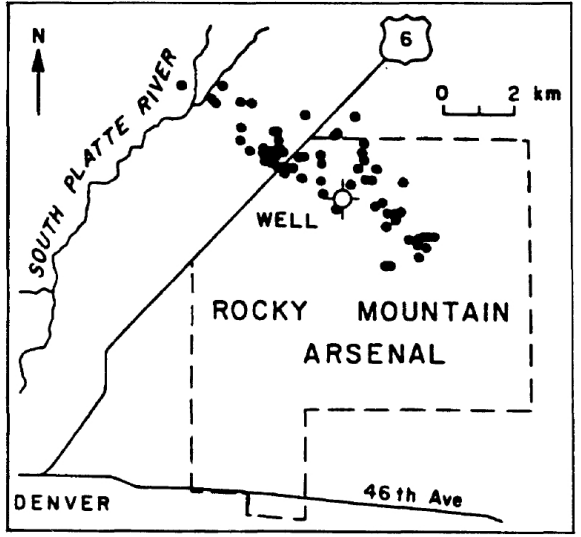

(a) Location of earthquakes

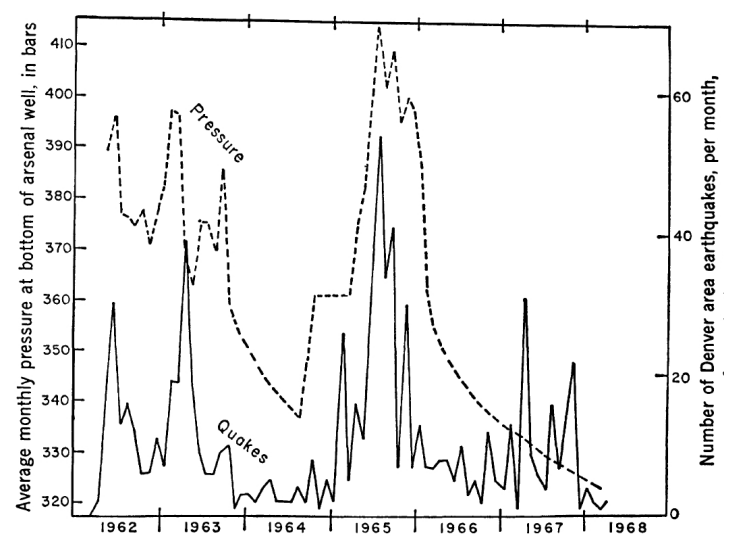

(b) Numbers of earthquakes and injection pressure

Fig. 1. Injection-induced seismicity at Rocky Mountain Arsenal (Nicholson \& Wesson, 1990) 
되었으며, 주요 진원지는 주입영역에 속하는 시추공 주 변의 심도 2-2.5 km 영역 한 곳과 시추공으로부터 1-2 $\mathrm{km}$ 떨어진 심도 3-5 km의 다른 한 곳으로 파악되었다 (Nicholson \& Wesson, 1990).

1970년 일본 Matsushiro 지역에서는 연구 목적으로 $2,900 \mathrm{~m}^{3}$ 의 물을 심도 $1.8 \mathrm{~km}$ 에서 1.4-5.0 MPa의 압력 으로 시간당 7.2-18.0 $\mathrm{m}^{3}$ 주입한 바 있으며, 실험이 진 행되는 두 달 동안 수백 회의 지진활동이 주입정 주변 $4 \mathrm{~km}$ 이내 1.5-7.5 km 심도에서 일어났다. 주입압력을 증가시켰을 때 5-9일이 지나서 지진활동 횟수도 증가 하였으며, 이러한 지연시간은 주변 지반의 유체투과도 (permeability) 추정 결과를 토대로 간극유압 변화가 전 파되는데 필요한 시간을 계산하였을 때 그 값과 일치하였 다(Nicholson \& Wesson, 1990). 한편 Zoback \& Harjes (1997)은 KTB(German Continental Deep Drilling Program) 의 고심도 시추공에서 약 $200 \mathrm{~m}^{3}$ 에 이르는 브롬화칼륨/ 염화칼륨 유체를 심도 9.03-9.10 km 구간에서 24시간 동안 주입한 후 12 시간 동안 시추공 압력을 유지하는 실험을 수행하였으며, 약 400 회의 미소진동(최대 $M_{L}$ 1.2 )이 감지되었다. 주입 시작 후 두 시간 경과했을 때 부터 지진활동이 일어나기 시작하여 주입 중단 후 약 24시간이 될 때까지 지속되었다. 지진활동 위치는 주입 구간보다 수백 미터 상부인 것으로 감지-지진활동 영 역의 중간지점 심도는 $8.8 \mathrm{~km}$ 이었음-되었는데, 시추 및 물리탐사 자료 분석 결과 해당 심도에 주요 단층영 역이 존재하였다. 단층대의 크기를 비롯한 몇 가지 조 건을 가정하고 주입압력을 토대로 간극유압 변화량을 계산한 결과 주입위치에 인접한 단층대에서도 압력 변 화는 최대 $1 \mathrm{MPa}$ 정도에 그치는 것으로 추정되었으나, 간극유압이 최대값에 도달하기 전 이미 해당 위치에서 지진활동이 일어났던 것으로 분석되었다. 이러한 결과 로부터 약 $260^{\circ} \mathrm{C}$ 의 고온 및 고심도 지반에서도 유체가
이동하며 임계응력 상태에 가까운 단층 영역이 존재하 는 점을 확인하였다.

\section{2 자연 생성된 $\mathrm{CO}_{2}$ 로 인한 지진활동}

지반 내 자연 생성되어 응집된 $\mathrm{CO}_{2}$ 가 여진 또는 지진 군(earthquake swarm)의 원인으로 추정된 대표적 사례 로는 이탈리아 북부 및 시칠리아, 일본 Matsushiro 지 역에서 발생하였던 지진을 들 수 있다. 1997년 이탈리 아 Apennines 산맥 북부 지역에서 두 차례 큰 정단층 지진 $\left(M_{L} 5.7\right.$ 및 6)이 일어난 후 30 일 이상 수천 번의 여진이 지속되었으며, 진원지는 북북서-남남동 방향으 로 길이 약 $40 \mathrm{~km}$ 폭 약 $15 \mathrm{~km}$ 에 걸쳐 광범위하게 분 포하였다. 일반적인 탄성 응력 전이 모델로는 이러한 현상을 설명하지 못했기 때문에 Miller et al.(2004)은 맨틀의 탈가스작용(mantle degassing)으로 생성된 고압 의 $\mathrm{CO}_{2}$ 가 지반 내에 갇혀 있다가 지진으로 인해 주변으 로 퍼져 나가면서 10-20 MPa에 이르는 압력 펄스로 작 용하는 모델을 제안하였으며, 조사된 진원지 위치와 수 치해석 결과를 비교함으로써 연구 결과의 타당성을 증 명하였다(Fig. 2). 시칠리아 북동부 Peloritani 산악지역 에서도 1994년과 2006년 사이 천여 번이 넘는 지진(1.0 $\left.\leq M_{L} \leq 3.3\right)$ 이 발생한 바 있는데, Giammanco et al.(2008) 은 역시 맨틀의 탈가스작용으로 생성된 고압의 유체가 지표면으로 이동하면서 지진군을 형성한 것으로 추정 하였다(Fig. 3). 즉 투수성이 낮은 지층의 하부에 다량 의 $\mathrm{CO}_{2}$ 와 $\mathrm{He}$ 이 포함된 가스가 응집되어 있던 중 높은 유체압력으로 인해 지층이 파열되는데, 이때 해당 위치 (Fig. 3 의 $\star$ 표시)에서 지진활동이 일어나며 누출된 $\mathrm{CO}_{2}$ 와 $\mathrm{He}$ 이 주요 단층을 통해 지표면으로 상승하던 중 대수층을 만나 물에 용해된 $\mathrm{CO}_{2}$ 는 $\mathrm{TV}$ 지역에서, 물을 통과한 $\mathrm{He}$ 은 R1 및 R2 지역에서 다량 배출되는 시나리 오를 제시하였다.

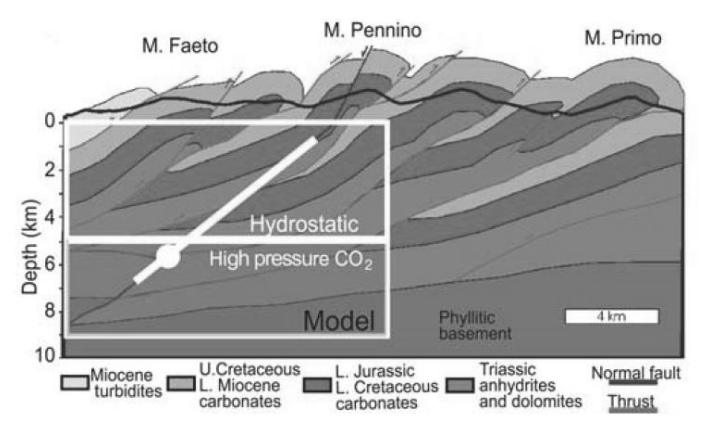

(a) Geologic cross-section

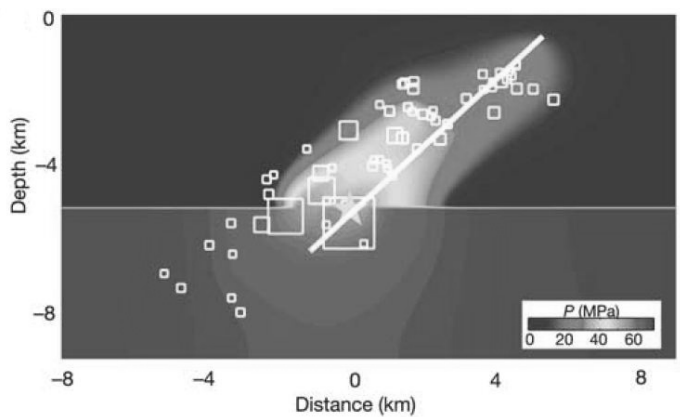

(b) Fluid pressure state and aftershock locations

Fig. 2. Comparison of aftershock data with pore pressure changes (Miller et al., 2004) 
일본 중부의 Matsushiro 지역에서도 1965년부터 2년 에 걸쳐 주향이동단층의 영향으로 700,000 회 이상의 지진이 일어나면서 지표면 변형과 균열이 발생하고 온 천 용출량이 증가하였다. 이 경우에도 다량의 $\mathrm{CO}_{2}$ 를 함 유한 유체의 상승 및 압력 증가가 원인으로 제시된 바 있으며, Cappa et al.(2009)은 수리-역학 연계 해석을 통해 지하 심부의 유체가 단층의 안정성 및 지반 변형 에 미치는 영향을 검토하였다.

\section{3. $\mathrm{CO}_{2}$ 지중 주입 시 단층 안정성 평가}

Rutqvist(2012)에 따르면 단층면에 인접한 지반의 응 력과 주변 암반의 평균적 응력상태는 국부적으로 상당 히 다를 수 있으며, 단층의 구조와 전단강도에 있어서

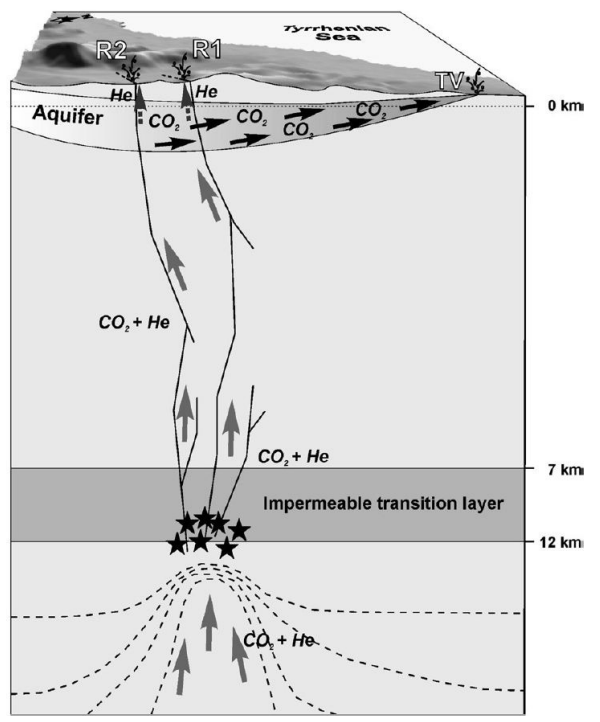

Fig. 3. Simplified model of gas transport and earthquake locations (Giammanco et al., 2008)
도 이방성이 있을 수 있기 때문에 $\mathrm{CO}_{2}$ 지중 주입 시 단 층이 언제, 어느 정도의 주입압력에서 활성화될 것인지 예측하는 것은 매우 어렵다. 그러나 이러한 한계에도 불 구하고 현재 $\mathrm{CO}_{2}$ 지중 주입과 관련된 다수 연구에서 개 략적인 단층 안정성 평가를 위해 공통적으로 적용되는 방법이 있으며, 본 장에서 그 과정을 간략히 소개하였다.

\section{1 단층 안정성 평가 방법}

단층의 안정성을 평가할 때는 대개 식 (1)과 같은 Mohr-Coulomb 파괴 기준을 적용하며, 단층면에 작용 하는 현지응력의 크기 및 방향, 단층 방향, 유체압력을 파악해야 한다. 유체를 주입함으로써 간극유체압력 $\left(P_{f}\right)$ 이 증가하면 단층면에 수직으로 작용하는 유효응력 $\sigma_{n}{ }^{\prime}=\left(\sigma_{n}-P_{f}\right)$ 은 감소하게 되고 단층면에 평행하게 작 용하는 전단응력 $(\tau)$ 에 저항하는 힘도 감소한다. 즉 간 극유체압력이 증가하면 Fig. 4와 같이 Mohr 원은 단층 파괴포락선 쪽으로 이동하게 되며 무결암보다 먼저 파 괴가 일어난다(Streit \& Hillis, 2004).

$$
\tau=C+\mu\left(\sigma_{n}-P_{f}\right)
$$

여기서 $\mu$ 는 정적 마찰계수이며 $C$ 는 단층의 거친 면 이 맞물릴 때 생기는 고유 전단강도이다. 점착력이 없 는 점토물질로 단층면이 덮여있는 경우 종종 고유 전단 강도는 무시할 수 있을 만큼 작은 값이 되므로(Byerlee, 1978; Shimamoto \& Logan, 1981) 식 (2)와 같이 전단 응력과 유효수직응력의 비가 단층의 정적 마찰계수와 같아질 때 미끄러짐이 일어나며 이로부터 단층의 미끄 러짐을 유발하는 유체압력 $\left(P_{f}^{c r i t}\right)$ 을 산정할 수 있다. 3 차원 공간에서 이러한 파괴 기준을 적용하는 과정은 Wiprut \& Zoback(2002)에 자세히 설명되어 있다.

$$
\frac{\tau}{\sigma_{n}-P_{f}^{\text {crit }}}=\mu
$$
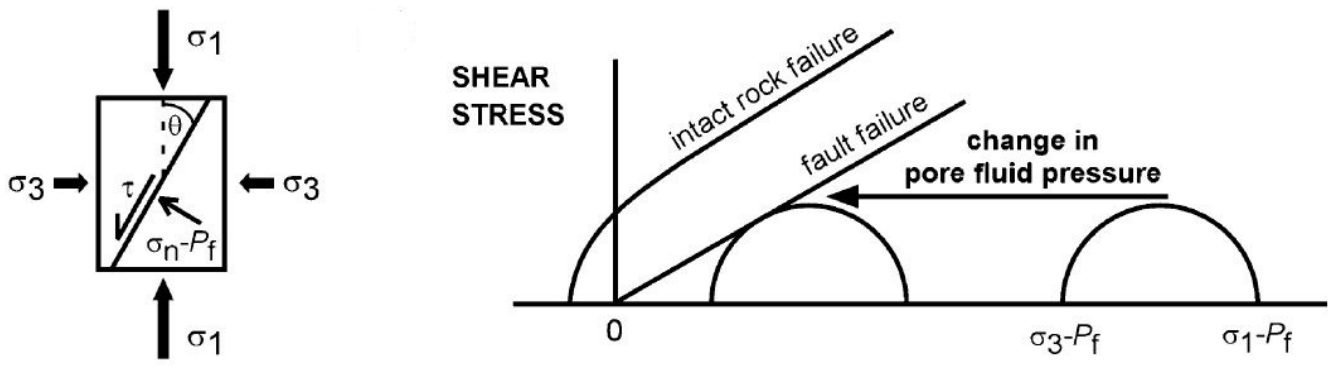

EFFECTIVE NORMAL STRESS

Fig. 4. Effect of increasing pore fluid pressure on fault stability (Streit \& Hillis, 2004) 


\section{2 현지응력의 방향 및 크기}

고심도 시추공을 이용한 지반조사 결과를 토대로 현 지응력의 방향과 크기를 구하는 과정은 다음과 같으며, 이 방법은 수직응력, 최대 및 최소 수평응력이 세 개의 주응력을 구성하는 것으로 가정하고 있다(Zoback et al., 2003; Lucier et al., 2006).

(1) 탄성파 속도 및 밀도 검층 결과를 이용하여 탄성 계수를 산정함

$\mathrm{P}$ 파 및 $\mathrm{S}$ 파 속도 $\left(V_{P}, V_{S}\right)$, 밀도 $(\rho)$ 와 같은 물리검층 결과를 이용하여 포아송비 $(\nu)$ 와 탄성계수 $(E)$ 를 구한다. 두 값은 Mohr-Coulomb 파괴조건 하에서 허용될 수 있 는 $S_{H \max }$ 범위를 한정하는데 이용된다(5) 항목 참고).

$$
\begin{aligned}
& \nu=\frac{V_{P}^{2}-2 V_{S}^{2}}{2\left(V_{P}^{2}-V_{S}^{2}\right)} \\
& E=2 \rho V_{S}^{2}(1+\nu)
\end{aligned}
$$

(2) 밀도 검층 결과를 누적하여 수직응력을 산정함 수직응력 $\left(S_{V}\right)$ 이 세 주응력 가운데 하나에 해당한다
는 가정 하에서 조사공의 깊이별 밀도를 누적한다.

$$
S_{V}=\int \rho(z) g d z=\sum \rho_{\text {avg }} g \Delta z
$$

여기서 $g$ 는 중력가속도, $z$ 는 심도이며, $\rho_{a v g}$ 는 구간 $\Delta z$ 의 평균 밀도이다.

(3) 시추공 영상촬영, 텔레뷰어, 공경검층(caliper logging) 자료 등을 이용해 시추로 인한 인장파괴(drilling-induced tensile failure) 또는 공벽파쇄(borehole breakout) 발생 위치를 확인하여 응력 방향을 결정함(Fig. 5)

수직시추공에서 시추공 벽면의 유효응력은 다음과 같 이 계산된다.

$$
\begin{aligned}
\sigma_{\theta \theta}= & S_{h \min }+S_{H \max }-2\left(S_{H \max }-S_{h \min }\right) \cos 2 \theta \\
& -2 P_{p}-\Delta P-\sigma^{\Delta T}
\end{aligned}
$$

$$
\sigma_{r r}=\Delta P
$$

$$
\sigma_{z z}=S_{V}-2 \nu\left(S_{H \max }-S_{h \min }\right) \cos 2 \theta-P_{p}-\sigma^{\Delta T}
$$

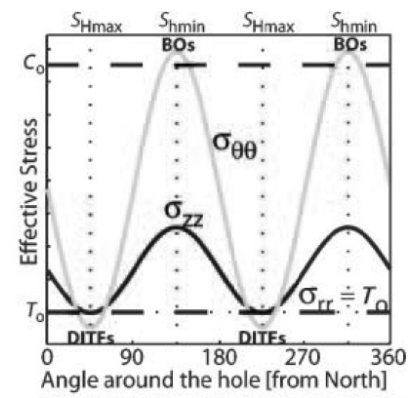

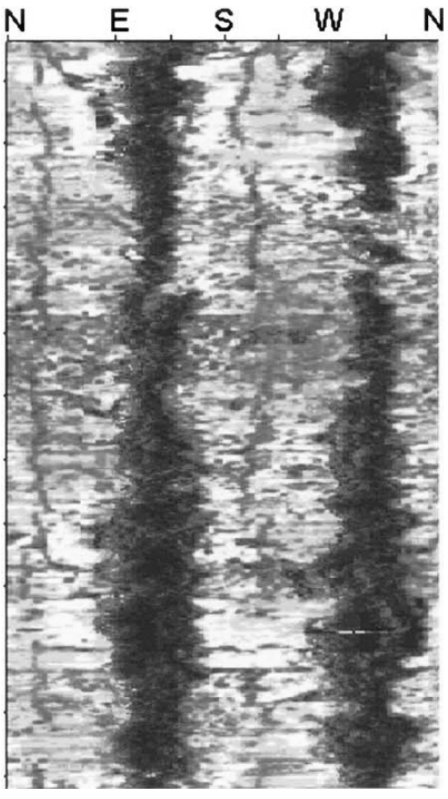

(b) Image logs of a well with wellbore breakouts

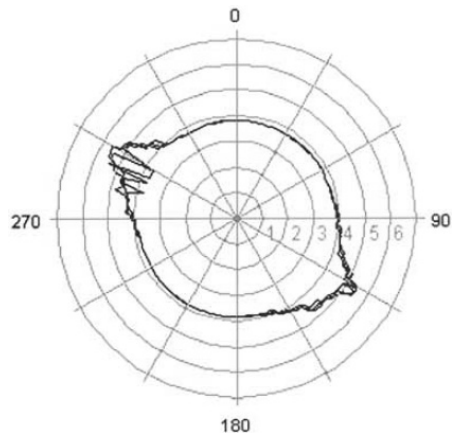

(c) Identification of wellbore breakout from cross-sections of a well

Fig. 5. Determination of horizontal stress orientation from drilling-induced wellbore failure (Zoback et al., 2003; Lucier et al., 2006) 
여기서 $\sigma_{\theta \theta}$ 는 접선응력, $\sigma_{r r}$ 은 반경방향응력, $\sigma_{z z}$ 는 수직응력이며, $\theta$ 는 $S_{H \max }$ 방향을 기준으로 측정된 방 위각이다. $P_{p}$ 는 간극유압이며 $\Delta P$ 는 시추이수 무게에 의한 시추공 압력과 간극유압의 차이, $\sigma^{\Delta T}$ 는 시추공에 서 $\Delta T$ 만큼 온도가 변화하면서 생성된 열응력이다. 시 추공 벽면에 응력이 집중될 때 현지응력 조건에 따라 접선응력이 인장으로 작용할 수 있으며 응력 크기가 암 석의 인장강도 $\left(T_{0}\right)$ 를 초과하면 인장파괴가 발생하고, 압축으로 작용하는 접선응력이 압축강도 $\left(C_{0}\right)$ 를 초과하 는 경우에는 공벽파쇄가 일어난다. 이때 인장파괴 방향 은 Fig. 5 와 같이 $S_{H \max }$ 의 방향과 같으며 공벽파쇄는 $S_{h \min }$ 방향에서 형성된다.

(4) 수압파쇄 시험결과로부터 $S_{h m i n}$ 범위 및 간극유압 $\left(P_{p}\right)$ 을 결정함

수압파쇄 시 주입률을 일정하게 유지하면 유체압력은 누출압력(Fig. 6의 LOP)에 도달하기 전까지 선형적으 로 증가하며, 이후 지층 내 균열이 발생하는 압력(FBP) 까지 공내 압력은 계속 증가한다. 압력에 의하여 암반 에 균열이 생성되면 공내 유체 손실이 일어나 압력은 감소하고, 균열이 $S_{h \min }$ 방향에 수직한 면을 따라 시추 공벽으로부터 확장되어 가는 동안 압력은 거의 일정한 값(FPP)을 나타낸다. 이때 유체 주입을 중단하면 균열 이 닫히는 것과 거의 동시에 압력이 급격히 떨어지면서 순간폐쇄압력(ISIP)에 이르렀다가 균열폐쇄압력(FCP) 까지 떨어진다. 순간폐쇄압력으로부터 $S_{h m i n}$ 의 크기를 파악할 수 있으며, 균열폐쇄압력으로 $S_{h m i n}$ 의 크기를 추정하기도 하는데 이 값은 유체의 점성이 낮고 펌프 압송률이 작을 때 순간폐쇄압력과 차이가 거의 없다 (Lucier et al., 2006). 한편 수압파쇄가 수행되기 전 각 시험구간마다 약 하루 동안 압력이 평형상태를 유지하
도록 하는데, 이 주입 전 압력(Fig. 6(b)에서 $P_{p}$ )을 측 정하면 해당 지층의 간극유압을 알 수 있다. 또한 여러 심도에서 측정된 값들을 회귀하여 심도에 따른 간극유 압의 변화를 파악해 놓음으로써 특정 심도의 간극유압 을 추정할 수 있다.

\section{(5) $S_{H \operatorname{Hax}}$ 범위를 한정함}

Anderson의 단층 분류체계와 Coulomb의 단층 이론 에 따르면 심도 및 간극유압, 지반의 마찰계수가 주어 졌을 때 지반 응력상태를 Fig. 7(a)와 같이 한정할 수 있다. $S_{H \max }$ 는 $S_{h \min }$ 보다 크거나 같기 때문에 그래프 의 대각선 상부 영역만 고려 대상이 되며, 세 응력 $S_{H \max }, S_{h \min }, S_{V}$ 의 크기가 동일한 점을 통과하는 수 평 및 수직선을 경계로 정단층(NF), 주향이동단층(SS), 역단층(RF) 영역으로 구분된다. $\mathrm{NF}$ 영역은 $S_{V} \geq S_{H \max }$ $\geq S_{h \min }$ 조건을 만족하며, 좌측의 수직경계(line 1)는 Jaeger \& $\operatorname{Cook(1979)}$ 이 제시한 최대 및 최소 주응력 비 조건에 따라 식 (9)를 통해 구해진다. $S_{H \max } \geq S_{h \min }$ $\geq S_{V}$ 조건에 해당하는 RF 영역을 제한하는 수평경계 (line 3)는 식 (10)으로 구할 수 있으며, 이때 $S_{H \max }$ 및 $S_{V}$ 로 Mohr 원을 형성하면 기울기가 $\mu$ 인 파괴포락선 에 접하게 된다. 따라서 파괴가 일어나지 않은 지반의 경우 어떤 응력상태라도 Fig. 7(a)의 다각형 내부에 포 함되어야 하며, 지반이 한계평형상태에 있다면 다각형 의 바깥쪽 경계선 상에 놓이게 된다. 지중유체 주입 등 으로 인해 간극유압이 증가하게 되면 Fig. 7(a)와 같이 다각형 영역의 크기가 축소되므로 작은 응력 변화에도 한계평형상태에 이를 가능성이 상대적으로 높아진다.

$$
\frac{\sigma_{1}}{\sigma_{3}}=\frac{S_{V}-P_{P}}{S_{h m i n}-P_{P}} \leq\left[\left(\mu^{2}+1\right)^{1 / 2}+\mu\right]^{2}
$$

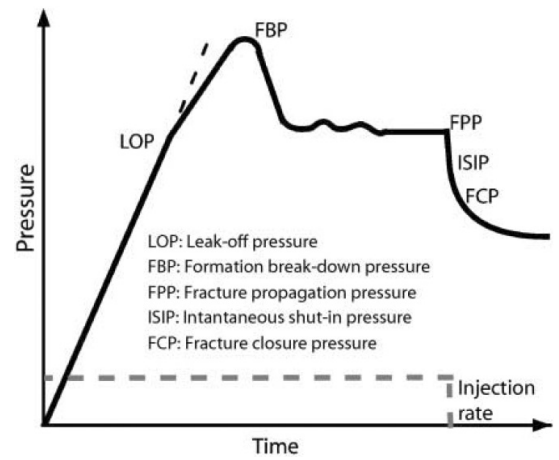

(a) Example of ideal minifrac test

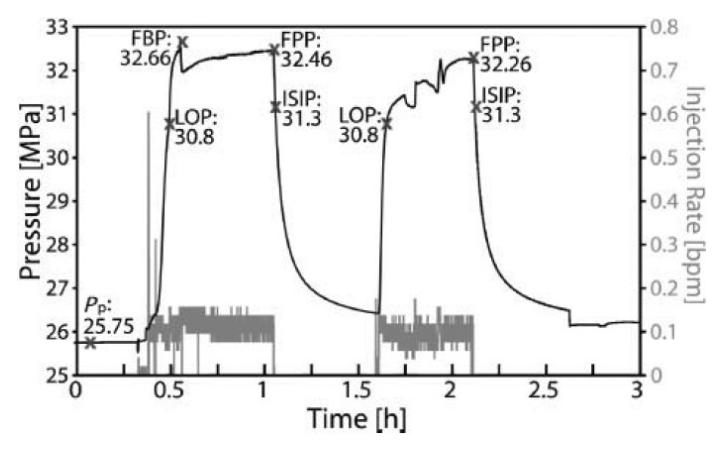

(b) Minifrac test in Rose Run Sandstone

Fig. 6. Minifrac test to measure $S_{\text {hmin }}$ magnitude (Gaarenstroom et al., 1993; Lucier et al., 2006) 

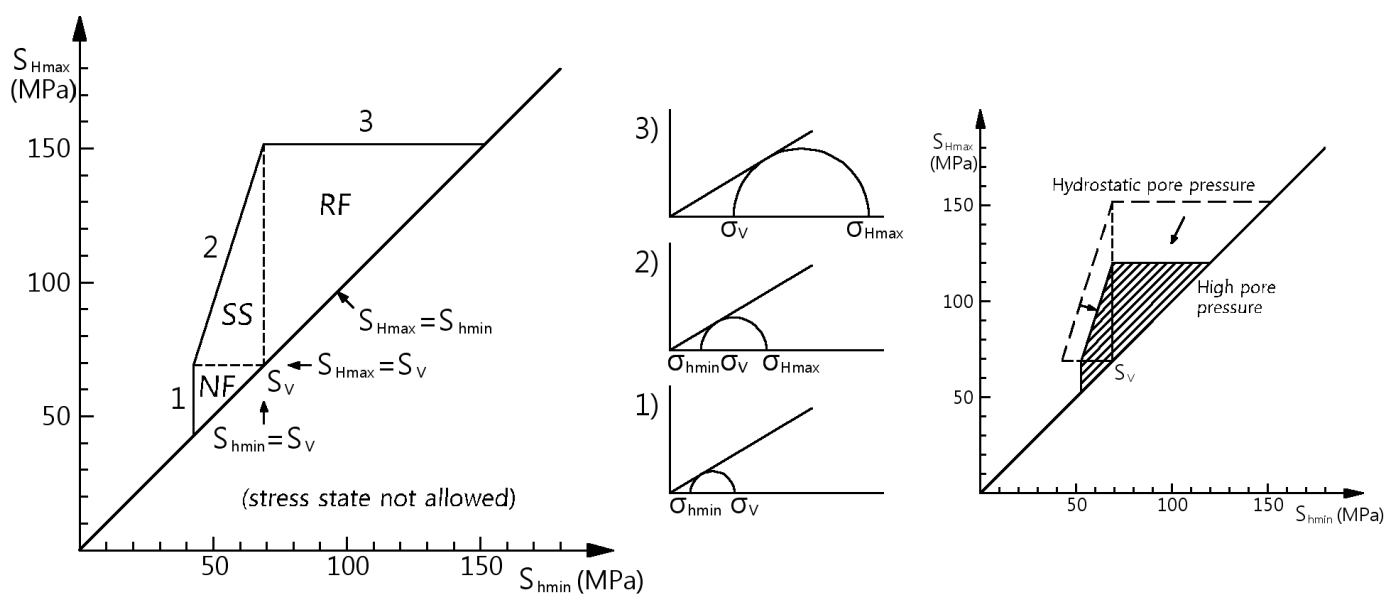

(a) Stress polygon defined by Anderson's faulting theory and Coulomb faulting theory

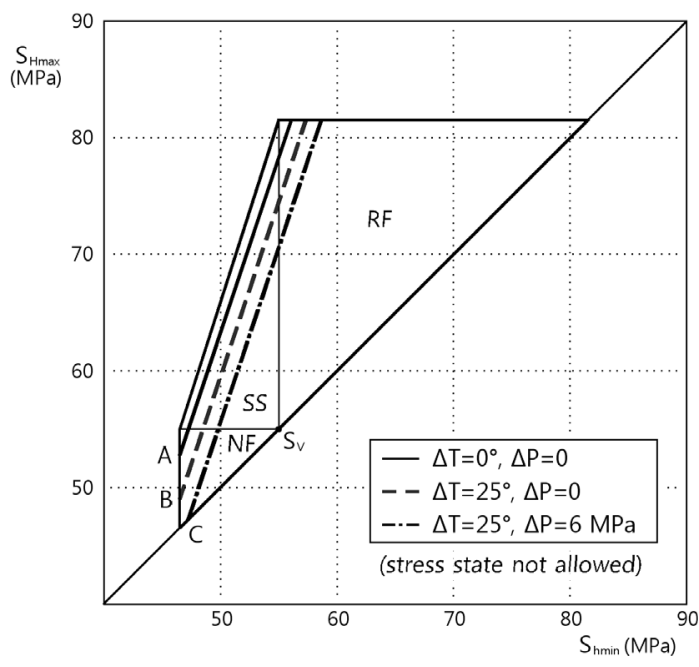

(b) $S_{\text {Hmax }}$ magnitude estimation based on drilling-induced tensile fractures

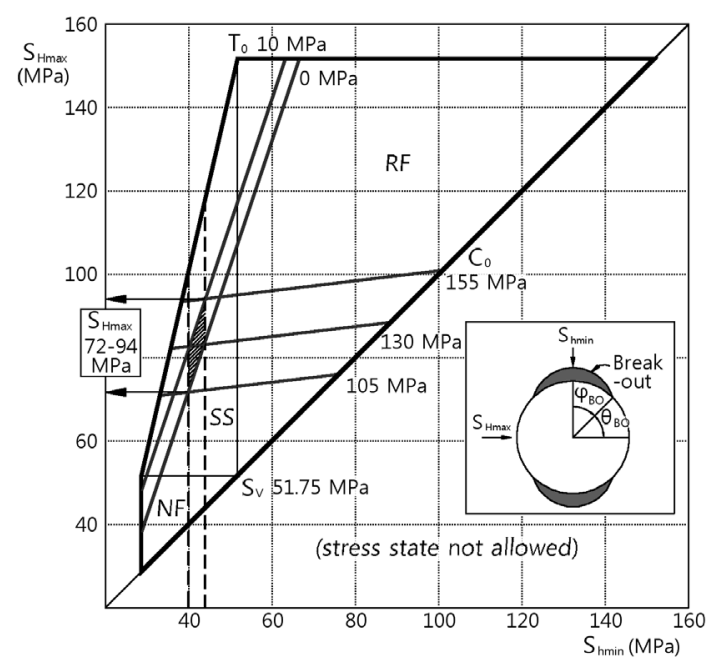

(c) $S_{H \max }$ magnitude estimation based on borehole breakout and $S_{\text {hmin }}$

Fig. 7. $S_{\text {Hmax }}$ magnitude estimation from constrain stress method (modified after Zoback et al., 2003; Lucier et al., 2006)

$\frac{\sigma_{1}}{\sigma_{3}}=\frac{S_{H \max }-P_{P}}{S_{V}-P_{P}} \leq\left[\left(\mu^{2}+1\right)^{1 / 2}+\mu\right]^{2}$

앞서 언급한대로 시추에 의해서 공벽에 인장균열이 생성되었을 때는 식 (6)을 이용해 구한 최소 접선응력 $\left(\sigma_{\theta \theta}^{\min }\right)$ 이 인장강도 $\left(-T_{0}\right)$ 보다 작아야 하며, 이때 $\Delta T$ 만 큼 온도가 변하면서 생성된 열응력은 식 (12)를 이용하 여 구할 수 있다.

$$
\sigma_{\theta \theta}^{\min }=3 S_{h \min }-S_{H \max }-2 P_{P}-\Delta P-\sigma^{\Delta T} \leq-T_{0}
$$

$$
\sigma^{\Delta T}=\frac{\alpha_{t} E \Delta T}{1-\nu}
$$

여기서 $\alpha_{t}$ 는 선형열팽창계수 $\left(1 /{ }^{\circ} \mathrm{C}\right)$ 로써 암반의 광물 조성에 따라 달라질 수 있다. Fig. 7(b)에서 다각형 내 line $\mathrm{A}$ 는 시추공 압력차 $(\Delta P)$ 및 냉각 $(\Delta T)$ 에 의한 영 향이 없는 것으로 가정하였을 때 식 (11)로부터 구한 $S_{h \min }$ 과 $S_{H \max }$ 의 관계를 나타낸다. 만약 인장파괴가 발생하였다면 최대수평주응력 값이 이 곡선보다 위쪽 에 위치해 있어야 하며, line $\mathrm{A}$ 는 지반응력의 크기를 제 한하는 하부경계가 된다. 한편 냉각에 의한 열응력을 
Table 2. Input data for the $S_{H m a x}$ constrain stress determination (Lucier et al., 2006)

\begin{tabular}{l|c}
\hline \multicolumn{1}{c}{ Input item } & Value \\
\hline Depth $(\mathrm{m})$ & 1,975 \\
\hline Vertical stress $S_{V}(\mathrm{MPa})^{*}$ & 51.75 \\
\hline Formation pressure $P_{P}(\mathrm{MPa})^{*}$ & 21.73 \\
\hline Wellbore failure type & Breakout, drilling-induced tensile fractures \\
\hline Breakout width $\left({ }^{\circ}\right)$ & 50 \\
\hline Poisson's ratio $\nu$ & 0.31 \\
\hline Young's modulus $E(\mathrm{GPa})$ & 74 \\
\hline Compressive strength $C_{0}(\mathrm{MPa})$ & $105-155$ \\
\hline $\begin{array}{l}\text { Temperature difference between drilling fluids } \\
\text { and formation temperate } \Delta T\left({ }^{\circ} \mathrm{C}\right)\end{array}$ & -7.8 \\
\hline Minimum horizontal stress $S_{\text {hmin }}(\mathrm{MPa})$ & $40-44$ \\
\hline
\end{tabular}

Note) The $S_{V}$ gradient is $26.2 \mathrm{MPa} / \mathrm{km}$, and the $P_{P}$ gradient is $11 \mathrm{MPa} / \mathrm{km}$. The coefficient of sliding friction $(\mu)$ equals 0.8 , and the coefficient of thermal expansion $\left(\alpha_{t}\right)$ equals $5.4 \times 10^{-6} /{ }^{\circ} \mathrm{C}$. The pressure difference between the well pressure and formation pressure $(\Delta P)$ equals zero.

고려하게 되면 인장파괴가 좀 더 쉽게 발생할 수 있기 때문에 line $\mathrm{B}$ 와 같이 더 작은 최대수평주응력 조건에 서 파괴가 일어날 수 있으며, 시추공 압력차까지 함께 고려한다면 경계선(line C)은 더 하향이동하게 된다.

시추공에서 공벽파쇄가 발생하였으며 파쇄영역의 폭 을 알고 있는 경우에는 공벽파쇄 발생영역 가장자리에 서의 응력이 암석강도와 동일하다는 가정 하에 Barton et al.(1988)에 의해 제안된 식 (13)을 이용하여 $S_{h m i n}$ 과 $S_{\text {Hmax }}$ 의 관계를 규정할 수 있다. 일례로 Ohio River Valley $\mathrm{CO}_{2}$ 저장 프로젝트에서 수행된 현지조사에서 인장파괴와 파쇄가 관찰되었을 때 조사 결과를 토대로 해당 심도에서의 최대수평주응력 크기 범위를 72-94 $\mathrm{MPa}$ 로 추정하였다(Fig. 7(c) 및 Table 2).

$$
S_{H \max }=\frac{\left(C+2 P_{P}+\Delta P+\sigma^{\Delta T}\right)-S_{h \min }\left(1+2 \cos 2 \theta_{B O}\right)}{1-2 \cos 2 \theta_{B O}}
$$

\section{3 단층 분포 파악}

미국 환경보호국(EPA)에서는 $\mathrm{CO}_{2}$ 지중저장에 사용 되는 주입정을 Class VI 시추정으로 분류하고 있으며, 소유주 또는 작업자가 시추정에 대한 허가를 얻고자 할 때는 지진활동이 지하수원이나 주입정, 주입 영역 등에 영향을 미치지 않는 점을 확인하기 위하여 최대 주입압 력 계획 및 해당 지역의 과거 지진활동 발생 이력과 더 불어 지반 응력 분포 자료, 저장영역의 지반공학적 정 보를 제출하도록 규제하고 있다(EPA, 2010). 또한 주
입위치 주변의 단층 분포에 대한 자료 역시 요구하고 있으며, 이에 대해 부지 특성 파악을 위한 지침을 제공 하고 있다(EPA, 2011). 지침에서는 광범위한 지역에서 지질 층위 및 구조, 지층 두께, 단층 등을 조사하는 방 법으로 주로 지구물리탐사를 제안하고 있으며, 탄성파 탐사, 중력탐사, 전자기/전기탐사, 자력탐사로 나누어 조사대상별로 적용성을 평가, 제시하고 있다(Table 3).

단층 분포 파악을 탐사 목적으로 하는 경우에 대해 간략히 살펴보면 탄성파탐사에서 2차원 및 3차원 지표 탄성파탐사, 시추공 간 탐사, 시추공 내 미소진동 측정 이 제시되었다. 2 차원 탐사의 경우 비용이 적게 들지만 탐사 측선의 방향이 단층 감지 결과에 영향을 줄 수 있으 며, 미소진동 측정은 단층에서 현재 변형이 진행되고 있 는 조건에서만 적용될 수 있다. 중력탐사는 밀도 차이로 단층을 감지하기 때문에 큰 규모의 평평한 단층을 찾을 가능성은 높지만 소규모 단층, 수직 단층 등은 감지하지 못할 수 있다(EPA, 2011). 물질의 전도 특성 차이를 이 용하여 단층을 구분하는 전자기/전기탐사의 경우에는 화 성암이나 변성암과 같이 단단한 지층 내에 존재하는 단 층을 찾을 때 유용한데, 암반의 간극비는 매우 작은 반면 상대적으로 단층을 채우고 있는 유체들은 주요 전도 경 로가 될 수 있기 때문이다(Orange, 1992). 끝으로 자력 탐사는 단층면을 따라 광물질이 제거(demineralization) 되거나 자철석의 광물화 등이 일어나서 자력 특성이 주 변 지반과 구별되는 점을 이용한다. 따라서 조사 결과 를 토대로 지층 특성을 규명하기는 어렵지만 단층과 같 은 지질구조 파악 목적으로 많이 사용된다. 국제에너지 
Table 3. Applicability of geophysical techniques to geological features of interest (EPA, 2011)

\begin{tabular}{|c|c|c|c|c|c|c|c|c|c|c|c|}
\hline \multirow[b]{2}{*}{ Investigation of } & \multicolumn{5}{|c|}{ Seismic } & \multicolumn{2}{|c|}{ Gravity } & \multicolumn{3}{|c|}{ Electromagnetic/electrical } & \multirow{2}{*}{\begin{tabular}{|c} 
Magnetic \\
Aerial \& \\
surface \\
magnetic
\end{tabular}} \\
\hline & $2 \mathrm{D}$ & $3 \mathrm{D}$ & $\begin{array}{l}\text { Vertical } \\
\text { seismic } \\
\text { profile }\end{array}$ & $\begin{array}{c}\text { Cross- } \\
\text { well }\end{array}$ & $\begin{array}{c}\text { Borehole } \\
\text { micro- } \\
\text { seismic }\end{array}$ & $\begin{array}{c}\text { Aerial \& } \\
\text { surface } \\
\text { gravity }\end{array}$ & $\begin{array}{c}\text { Borehole } \\
\text { gravity }\end{array}$ & $\begin{array}{l}\text { Natural } \\
\text { source }\end{array}$ & $\begin{array}{c}\text { Controlled } \\
\text { source }\end{array}$ & $\begin{array}{c}\text { Electrical } \\
\text { resistance } \\
\text { tomography }\end{array}$ & \\
\hline $\begin{array}{l}\text { Near borehole and } \\
\text { shallow subsurface }\end{array}$ & & & $\mathrm{W}$ & $\mathrm{W}$ & $\mathrm{W}$ & & $\mathrm{W}$ & & $\mathrm{W}$ & & \\
\hline $\begin{array}{c}\text { Field-wide } \\
\text { subsurface studies }\end{array}$ & $\mathrm{W}$ & W & & & $\mathrm{P}$ & $\mathrm{W}$ & & $\mathrm{W}$ & $\mathrm{W}$ & & $\mathrm{W}$ \\
\hline Stratigraphy & $\mathrm{W}$ & W & $\mathrm{W}$ & $\mathrm{W}$ & & $\mathrm{W}^{1}$ & $\mathrm{~W}$ & $P$ & $P$ & $\mathrm{~W}$ & $\mathrm{P}^{2}$ \\
\hline Thickness & $\mathrm{W}$ & $\mathrm{W}$ & $\mathrm{W}$ & $\mathrm{W}$ & & & $\mathrm{W}$ & & & $\mathrm{W}$ & \\
\hline Structure $(0-100 \mathrm{~m})$ & & & & & $P$ & $P$ & & $P$ & $P$ & $P$ & $P$ \\
\hline $\begin{array}{c}\text { Structure } \\
(100 \mathrm{~m}-1 \mathrm{~km})\end{array}$ & $\mathrm{W}$ & W & & $\mathrm{W}$ & $\mathrm{W}$ & $\mathrm{P}$ & $\mathrm{P}$ & $\mathrm{P}$ & $\mathrm{P}$ & $\mathrm{W}$ & $\mathrm{P}$ \\
\hline Structure $(>1 \mathrm{~km})$ & $\mathrm{W}$ & W & & $P$ & $\mathrm{~W}$ & $\mathrm{~W}^{3}$ & $P$ & $\mathrm{~W}$ & $\mathrm{~W}$ & $P$ & $\mathrm{~W}^{3}$ \\
\hline Fault/fracture & $\mathrm{W}$ & W & & $\mathrm{W}$ & $\mathrm{W}^{4}$ & $\mathrm{P}$ & & $\mathrm{P}^{5}$ & $\mathrm{~W}^{5}$ & $\mathrm{P}^{5}$ & $\mathrm{~W}$ \\
\hline Porosity & & & & & & $\mathrm{P}$ & $\mathrm{W}$ & $\mathrm{W}^{6}$ & $\mathrm{~W}^{6}$ & $\mathrm{~W}^{6}$ & \\
\hline Pore pressure & $\mathrm{P}$ & W & $\mathrm{P}$ & $\mathrm{P}$ & & & & & & & \\
\hline Abandoned wells & & & & & & & & & & $\mathrm{W}$ & $\mathrm{W}^{7}$ \\
\hline
\end{tabular}

$\mathrm{W}=$ Well suited (e.g. already in use for site characterization with good results);

$\mathrm{P}=$ Potential (e.g. could be used, but often not used because better alternatives are available or in use but results are not as resolved as desired).

1) Valid for flows, sills, channel fills, or other discontinuous units with high density contrast.

2) Chiefly for iron-mineral bearing units (e.g. mafic intrusions, red-beds, etc.)

3) Characterizes depth to basement.

4) Valid only if faults/fractures are actively undergoing deformation.

5) Valid only in non-porous formations.

6) Qualitative estimates compared to nearby formations.

7) Valid only if wells are cased in the near surface with metal.

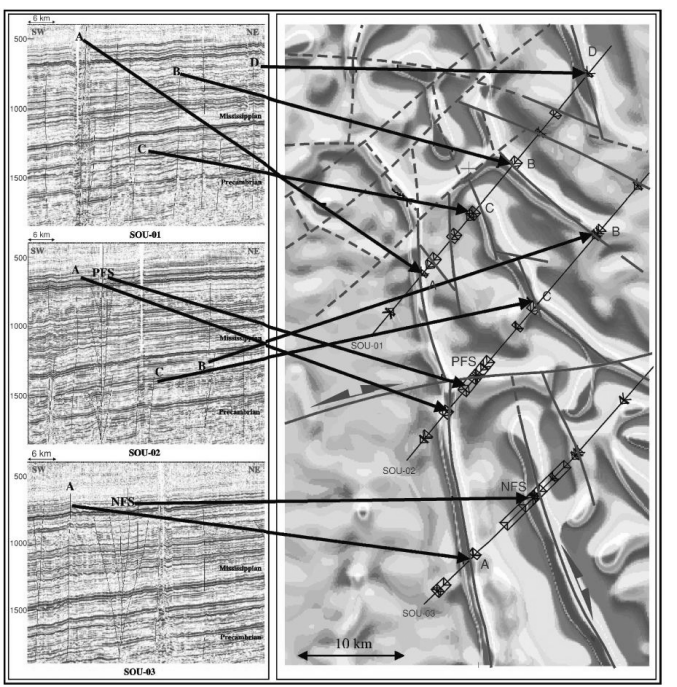

Fig. 8. Comparison of seismic survey results and the HRAM data from the Weyburn $\mathrm{CO}_{2}$ sequestration project (Nabighian et al., 2005)
기구(IEA) Weyburn $\mathrm{CO}_{2}$ 저장 프로젝트에서는 $\mathrm{HRAM}$ (high-resolution aeromagnetic) 탐사 결과를 이용하여 여섯 개 단층(Fig. 8의 A-D, PFS, NFS)의 위치를 찾아 낸 바 있다. 특히 단층 $\mathrm{A}$ 의 경우 선행된 탄성파탐사 (SOU-\#1-3) 세 측선 모두에서 탐지되었으나 단층의 연 결성까지는 추정하지 못했으며, 자력탐사 결과를 확인 한 후에야 대규모 단층임을 알고 Souris River 단층으 로 명명하였다(Nabighian et al., 2005).

\section{4 유체압력 모델링}

단층 안정성을 평가할 때는 현지응력의 크기 및 방향 과 더불어 단층에 작용하는 유체압력을 추정할 수 있어 야 한다. 이를 위해 주로 수치 시뮬레이션을 이용하여 $\mathrm{CO}_{2}$ 지중 주입 시 암반 내 유체의 흐름과 분포를 파악 하며, 그 결과는 부지 선정과 특성 파악, 모니터링 위치 선정 등에 있어서도 중요한 판단 근거가 된다. 이러한 수치 시뮬레이션 방법들은 탄화수소 생산, 지열에너지 생산, 지하수 관리 등에 적용되어 이미 검증되었기 때문 
에 $\mathrm{CO}_{2}$ 지중저장 분야에서도 충분히 활용될 수 있는 것 으로 평가받고 있다(NETL, 2011). 시뮬레이션 과정에 서는 Fig. 9와 같이 열-수리-역학적-화학적 모델(coupled THMC model)을 이용하여 응력, 간극비 및 유체투과 도, 유체압력, 온도, 침전 등에 대해 일방향 또는 양방향 연계 해석을 수행한다. 이를 토대로 암반층의 파쇄 가 능성, 단층을 포함한 기존 불연속면의 활성화 여부 등 지중저장영역의 건전성을 검토할 뿐만 아니라 시간 경 과에 따른 $\mathrm{CO}_{2}$ 플럼의 형성 범위, $\mathrm{CO}_{2}$ 주입에 의해 유 발된 화학작용이 간극비 및 유체투과도, 점토광물의 팽 창 등에 미치는 영향 등에 대해서도 파악할 수 있다. 하 지만 검토 목적 및 상황에 따라 해석적 해 또는 단순화 된 수치 해를 이용하여 지반 내 유체 흐름을 추정하기 도 한다(Celia \& Nordbotten, 2011).

$\mathrm{NETL}$ (2011)에 따르면 $\mathrm{CO}_{2}$ 지중저장 시뮬레이션과 관련된 수치 해석 코드로는 Table 4 와 같은 프로그램들

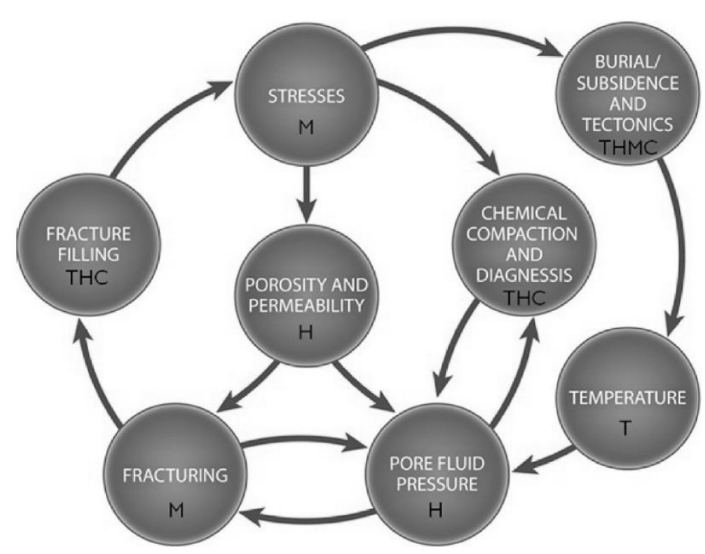

Fig. 9. Potential coupling of physical processes during subsurface $\mathrm{CO}_{2}$ storage (NETL, 2011)

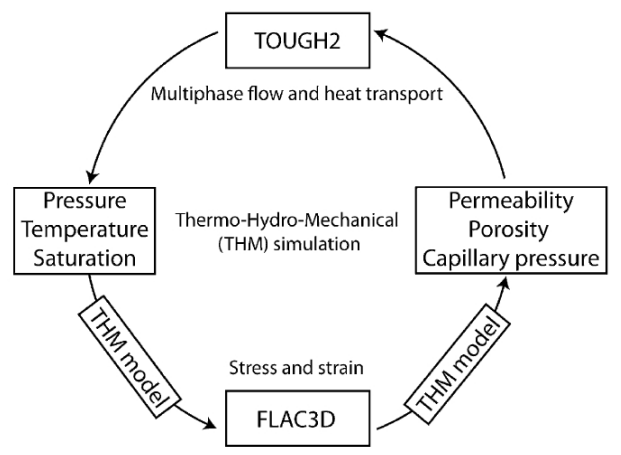

(a) TOUGH-FLAC
이 있다. 이 중에서 TOUGH2는 다공성 및 파쇄된 매질 에서의 다상유체 흐름과 열전달을 모사할 수 있는 범용 프로그램이며, STOMP-WCSE는 염대수층에 $\mathrm{CO}_{2}$ 주입 시, Eclipse, GEM, COMET3 등은 탄화수소 저류층에 주입 시 지반 내 유체 흐름과 열전달을 연구할 목적으 로 사용된 바 있다. 한편 유체압력은 지반 응력에 영향 을 미치고 응력 변화 및 지반 변형은 다시 유체투과도 에 영향을 미치므로 수리-역학적 관계가 주요 관심 대 상인 경우에는 $\mathrm{ABAQUS}, \mathrm{FLAC}^{3 \mathrm{D}}$, VISAGE와 같은 프로그램을 이용, Fig. 10과 같은 형태로 연계 해석을 수행한다(Cappa \& Rutqvist, 2011b; Ouellet et al., 2011).

\section{4. 단층 안정성 평가 연구 동향}

\section{1 단층 활성화 가능성 추정}

$\mathrm{CO}_{2}$ 지중 주입으로 인한 단층 활성화 가능성은 주로 스테레오넷을 작성하여 검토한다. 추정된 현지응력 조 건에서 임의의 단층 방향을 가정하고 $\mathrm{Mohr}$ 원이 파괴 포락선에 접하는데 필요한 간극유압 증가량(Fig. 4)을 계산하여 스테레오넷의 해당 위치(단층면의 극점)에 표 시한다. Ohio River Valley 지역 심부 염대수층에 $\mathrm{CO}_{2}$ 를 저장하는 프로젝트에서 Lucier et al.(2006)은 덮개 암의 현지응력을 조사하여 Fig. 11과 같은 결과를 얻었 으며, 약 $1 \mathrm{MPa}$ 의 유체압력 증가에도 단층 방향에 따 라 미끄러짐이 일어날 가능성이 있음을 확인하였다. 즉 스테레오넷 상의 흰색 점(A, $\left.\mathrm{A}^{\prime}, \mathrm{B}, \mathrm{B}^{\prime}\right)$ 이 조사된 지반 조건에서 상대적으로 작은 유체압력 증가에도 미끄러 질 수 있는 단층 방향이 된다. 따라서 $\mathrm{CO}_{2}$ 지중 주입으 로 유체압력이 증가할 때 덮개암에 북북동 방향 또는 동북동 방향으로 거의 수직에 가까운 주향이동단층이 존재한다면 그 단층면에서 가장 먼저 미끄러짐이 발생

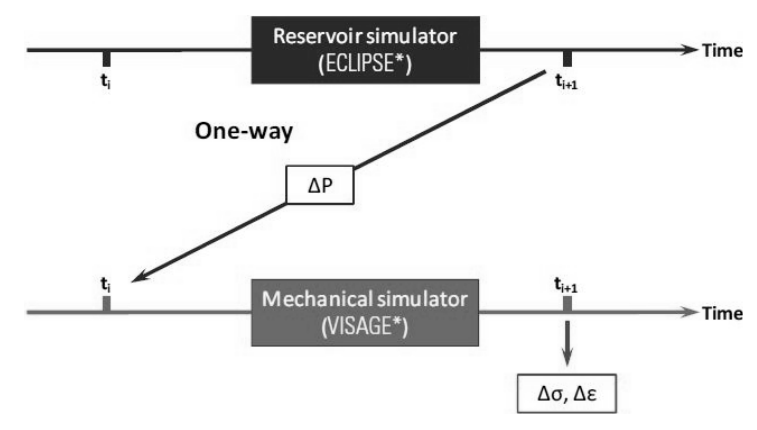

(b) ECLIPSE-VISAGE

Fig. 10. Schematic of coupled (thermo)-hydro-mechanical simulations (Cappa \& Rutqvist, 2011b; Ouellet et al., 2011) 
Table 4. Numerical codes for geologic $\mathrm{CO}_{2}$ storage simulation (NETL, 2011)

\begin{tabular}{|c|c|c|c|}
\hline Code & Developer & Coupling & Processes modeled \\
\hline NFFlow-FRACGEN & NETL & $\mathrm{H}$ & Two-phase, multi-component flow in fractured media \\
\hline Eclipse & Schlumberger & $\mathrm{T}, \mathrm{H}$ & Non-isothermal multiphase flow in porous media \\
\hline MASTER & NETL & $\mathrm{T}, \mathrm{H}$ & Black oil simulator, compositional multi- phase flow \\
\hline TOUGH2 (TOUGH+) & LBNL & $\mathrm{T}, \mathrm{H}$ & $\begin{array}{l}\text { Non-isothermal multiphase flow in unfractured and fractured } \\
\text { media }\end{array}$ \\
\hline GMI-SFIB & $\begin{array}{l}\text { Geomechanics } \\
\text { International }\end{array}$ & M & $\begin{array}{l}\text { Three-dimensional stress modeling for compressional } \\
\text { (wellbore breakout) and tensional (tensile wall fractures) stress } \\
\text { failure, fracture modeling }\end{array}$ \\
\hline ABAQUS & SIMULIA & $\mathrm{T}, \mathrm{M}$ & Geomechanical, single- and two-phase flow \\
\hline COMET3 & ARI & $\begin{array}{l}\mathrm{T}, \mathrm{H}, \mathrm{M} \\
\text { sorption }\end{array}$ & $\begin{array}{l}\text { Black oil production, hydrocarbon recovery from } \\
\text { desorption-controlled reservoirs }\end{array}$ \\
\hline TOUGH-FLAC & LBNL & $\mathrm{T}, \mathrm{H}, \mathrm{M}$ & $\begin{array}{l}\text { Non-isothermal multiphase flow in unfractured and fractured } \\
\text { media with geomechanical coupling }\end{array}$ \\
\hline $\begin{array}{l}\text { The Geochemist's } \\
\text { Workbench }\end{array}$ & University of Illinois & $\mathrm{C}$ & Chemical reactions, pathways, kinetics \\
\hline PSU-COALCOMP & $\begin{array}{c}\text { Penn State } \\
\text { University/NETL }\end{array}$ & $\begin{array}{l}\mathrm{T}, \mathrm{H} \\
\text { sorption }\end{array}$ & Compositional simulator with dual porosity, sorption \\
\hline CrunchFlow & LLNL & $\mathrm{T}, \mathrm{H}, \mathrm{C}$ & $\begin{array}{l}\text { 3-D, multiphase transport with equilibrium and kinetic } \\
\text { mineral-gas-water reactions }\end{array}$ \\
\hline GEM-GHG & $\begin{array}{l}\text { Computer Modelling } \\
\text { Group Ltd. }\end{array}$ & $\mathrm{T}, \mathrm{H}, \mathrm{C}$ & Non-isothermal multiphase flow in porous media \\
\hline NUFT-C & LLNL & $\mathrm{T}, \mathrm{H}, \mathrm{C}$ & $\begin{array}{l}\text { Non-isothermal multiphase flow and chemical reactions in } \\
\text { porous media }\end{array}$ \\
\hline PFLOTRAN & LANL & $\mathrm{T}, \mathrm{H}, \mathrm{C}$ & $\begin{array}{l}\text { Non-isothermal multiphase, multicomponent, chemically reactive } \\
\text { flows in porous media. Can be run coupled or uncoupled }\end{array}$ \\
\hline PHAST & USGS & $\mathrm{T}, \mathrm{H}, \mathrm{C}$ & $\begin{array}{l}\text { Multicomponent, 3-D transport with equilibrium and kinetic } \\
\text { mineral-gas-water reactions }\end{array}$ \\
\hline STOMP-family of codes & PNNL & $\mathrm{T}, \mathrm{H}, \mathrm{C}$ & $\begin{array}{l}\text { Non-isothermal multiphase flow in porous media, coupled with } \\
\text { reactive transport }\end{array}$ \\
\hline TOUGHREACT & LBNL & $\mathrm{T}, \mathrm{H}, \mathrm{C}$ & $\begin{array}{l}\text { Non-isothermal multiphase flow in unfractured and fractured } \\
\text { media with reactive geochemistry }\end{array}$ \\
\hline $\begin{array}{l}\text { OpenGeoSys:[Couples } \\
\text { GEM, BRNS, PHREEQC, } \\
\text { ChemApp, Rockflow] }\end{array}$ & $\begin{array}{l}\text { UFZ-BGR-CAU-GFZ } \\
\text {-PSI-TUD-UE }\end{array}$ & $\mathrm{T}, \mathrm{H}, \mathrm{M}, \mathrm{C}$ & Porous and fractured media THMC simulation \\
\hline FEHM & LANL & $\mathrm{T}, \mathrm{H}, \mathrm{M}, \mathrm{C}$ & $\begin{array}{l}\text { Non-isothermal, multiphase flow (including phase-change) in } \\
\text { unfractured and fractured media with reactive geochemistry } \\
\& \text { geo- mechanical coupling }\end{array}$ \\
\hline CO2-PENS & LANL & - & $\begin{array}{l}\text { Systems-level modeling of long-term fate of } \mathrm{CO}_{2} \text { in } \\
\text { sequestration sites }\end{array}$ \\
\hline COMSOL & COMSOL & - & $\begin{array}{l}\text { General partial differential equation solver with finite element } \\
\text { solver }\end{array}$ \\
\hline
\end{tabular}

할 것으로 추정되었다. 다만 이러한 추정 결과는 단층 면의 마찰계수 $(\mu)$ 를 0.6으로 가정한 경우이며 이 값이 커질수록 지진활동을 유발하는 유체압력의 크기는 증
가하게 된다.

미국 와이오밍 Teapot dome 유전지역 내 Tensleep 지층에 $\mathrm{CO}_{2}$-EOR(enhanced oil recovery) 주입정을 설 
치하는 과정에서 Fig. 12와 같이 3차원 탄성파탐사에 의해 파악된 주요 단층을 대상으로 지진활동 발생 가능 성이 평가되었다(Chiaramonte et al., 2008). 현지조사 결과에 따라 단층면 각 위치에서의 전단 및 수직응력, 간극유압을 구한 뒤 마찰계수을 가정하고 미끄러짐을 유발하는 유체압력(Fig. 12에서는 유체압력 증가량을 나 타냄)을 추정하였다. 검토 결과 해당 지층의 단층영역 에서는 유체압력이 약 $17 \mathrm{MPa}$ 증가 $\left(\mathrm{CO}_{2}\right.$ 기둥 높이로 환산 시 약 $2,500 \mathrm{~m}$ 해당)했을 때 미끄러짐이 일어날 것으로 예측되었으나, Tensleep 지층 주변에 $\mathrm{CO}_{2}$ 가 축 적되더라도 압력이 $100 \mathrm{~m}$ 를 넘지 않을 것으로 평가되 었다. 한편 이 연구에서는 탄화수소 및 지열 저류층의 폭이 두께보다 열 배 이상 큰 평평한 지층일 때 식 (14) 와 같이 간극유압의 변화가 수평응력에 미치는 영향 (Segall \& Fitzgerald, 1998)도 함께 고려하였으며, 이 를 반영하여 검토한 결과 단층 주변에서 유체압력 증가 량이 약 $20 \mathrm{MPa}$ 에 도달하지 않는다면 단층은 안정할

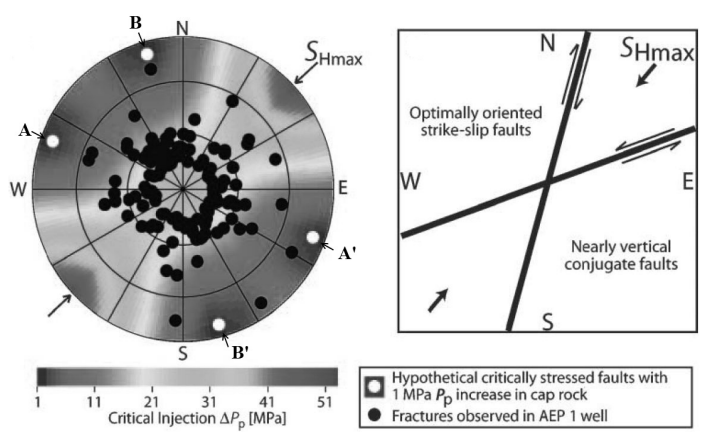

Fig. 11. Lower hemisphere stereonet plot of critical pore pressure changes (Lucier et al., 2006)



(a) not-considering poro-elastic effect
것으로 예측되었다(Fig. 12(b)).

$$
\Delta \sigma_{h}=\alpha \frac{1-2 \nu}{1-\nu} \Delta P_{P}
$$

여기서 $\alpha$ 는 Biot 수이며 $\nu$ 는 포아송비이다.

CO2CRC(Cooperative Research Centre for Greenhouse Gas Technologies)에서 수행중인 Otway 프로젝트에서 는 시추조사와 물리탐사 결과에 차이가 있었으며 이를 보완할 목적으로 현지응력에 대한 다수의 시나리오를 구성하고 주변 단층의 안정성을 평가하였다. 시나리오 는 크게 주향이동단층이 유발될 수 있는 응력조건과 정 단층이 유발될 수 있는 조건으로 나뉘며, 주향이동단층 을 가정한 경우에 시추 및 물리탐사 결과에 따라 최대 수평주응력 크기를 다르게 적용하였다. 또한 저류층 특 성을 반영할 수 있도록 식 (14)에서 Boit 수와 포아송비 를 다르게 하여 단층 활성화 가능성을 평가하였다(Fig. 13). 검토 결과 가장 좋지 않은 조건에서는 $2 \mathrm{MPa}$ 의 유 체압력 증가에도 단층이 미끄러질 수 있으며, 최대수평 주응력이 큰 경우에는 $17 \mathrm{MPa}$ 까지 유체압력이 증가하 여도 단층이 안정할 수 있음을 보였다(Vidal-Gilbert et al., 2010).

Mendes et al.(2010)의 연구 시례에서는 브라질 Miranga 유전지역 저류층 내 $\mathrm{CO}_{2}$ 지중저장 안정성을 평가하는 과정에서 2 차원 유한요소 모델을 구성하고 단층의 점착 력 및 마찰각, 수직 및 전단강성, 유효 단위중량, 측압계 수 등 지반 물성에 대한 민감도 분석을 수행하였다. 또 한 몬테카를로 시뮬레이션 기법을 적용, 다수의 해석 수행 결과를 분석하여 유체압력 증가량에 따른 단층 활 성화 확률 추정 곡선을 제시하였다(Fig. 14).

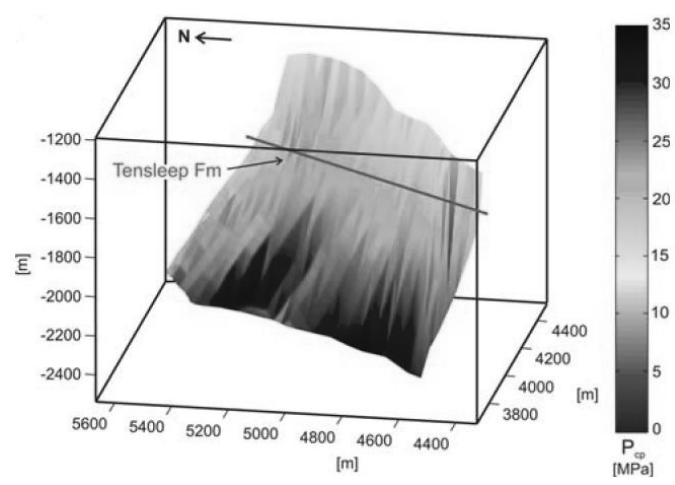

(b) Considering poro-elastic effect

Fig. 12. Fault surface color-coded with critical pressure perturbation values indicating the fault slip potential (Chiaramonte et al., 2008) 


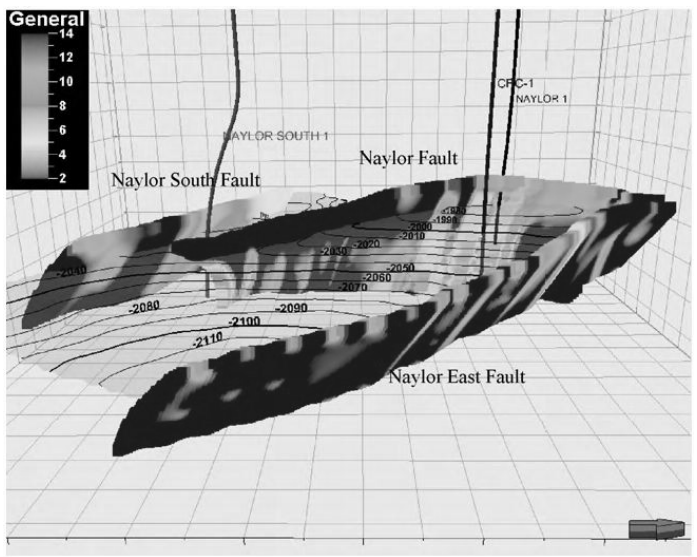

(a) Strike-slip fault assumption

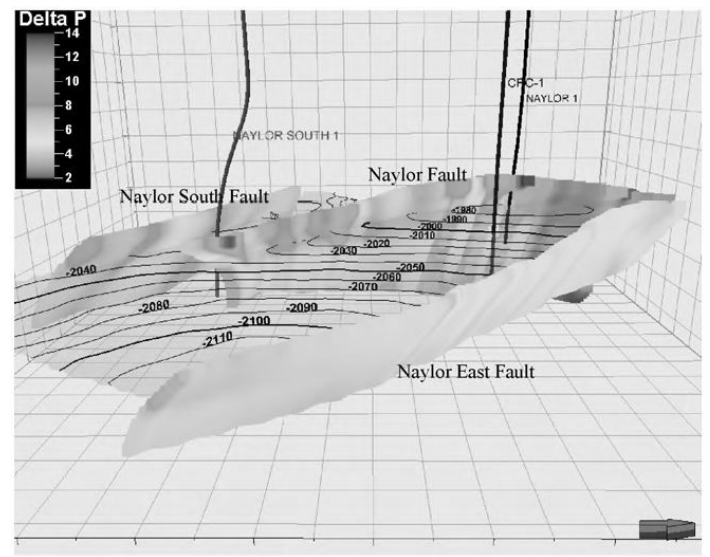

(b) Normal fault assumption

Fig. 13. Fault reactivation propensity in the Naylor Field, Otway Basin, Australia (Vidal-Gilbert et al., 2010)

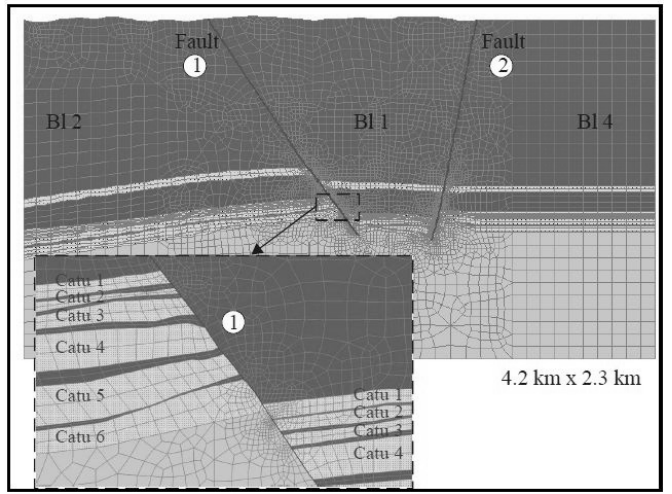

(a) Finite element model

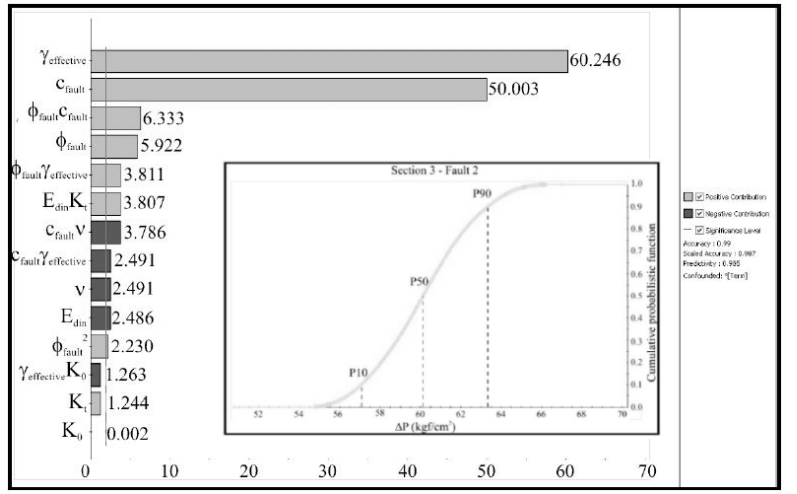

(b) Sensibility analysis of geotechnical parameters

Fig. 14. Probabilistic analysis for estimating the effect of geotechnical factors on fault opening (Mendes et al., 2010)

\section{2 단층 활성화에 의한 지진활동 크기 추정}

$\mathrm{CO}_{2}$ 지중 주입에 의해 단층이 활성화될 때 미끄러짐 이 일어난 영역 크기와 평균 변위(mean slip)를 추정할 수 있다면 지진활동의 크기도 대략 예측할 수 있다. Cappa \& Rutqvist(2011a)는 Fig. 15(a)와 같이 $2 \mathrm{~km}$ $\times 2 \mathrm{~km}$ 크기의 2차원 평면변형률 모델을 TOUGH-FLAC 으로 모사한 후 단층이 임계상태에 가깝도록 현지응력 조 건을 구성하였다. 그리고 단층으로부터 $500 \mathrm{~m}$ 떨어진 위 치에서 $\mathrm{CO}_{2}$ 가 주입되는 과정을 모사하였다. 단층모델로 는 초기 항복 전단응력 이후 잔류 전단응력까지 감소하면 서 임계 변위(critical slip)가 발생하는 slip-weakening 모 델(Kanamori \& Brodsky, 2004)을 사용하였으며, 전단 발생으로 인한 단층의 유체투과도 변화까지는 고려하 지 않았다. 검토 결과 $\mathrm{CO}_{2}$ 를 630.72 tons $/ \mathrm{m} / \mathrm{year}$ 속도
로 일정하게 주입했을 때 90 일 경과 후 미끄러짐이 일 어났으며, 최종적으로는 폭 $385 \mathrm{~m}$ 영역에 걸쳐서 평균 $0.08 \mathrm{~m}$ 의 미끄러짐과 평균 $0.42 \mathrm{MPa}$ 의 응력저하(최대 $2 \mathrm{MPa}$ )가 발생하였다. 이 결과로부터 식 (15)를 이용하 여 지진모멘트(seismic moment) $M_{0}$ 가 $1.23 \times 10^{14} \mathrm{~N} \cdot \mathrm{m}$ 인 것으로 추정하였으며, 식 (16)을 이용하여 모멘트 규 모 $M_{w}$ 3.4를 구하였다(Kanamori \& Brodsky, 2004).

$$
\begin{aligned}
& M_{0}=G A d \\
& M_{w}=\frac{2}{3} \log _{10} M_{0}-6.07
\end{aligned}
$$

여기서 $G$ 는 단층의 전단강성이며 $A$ 는 미끄러짐이 
발생한 영역의 면적, $d$ 는 미끄러짐 평균 길이이다. 식 (16)에서 $M_{0}$ 의 단위는 $\mathrm{N} \cdot \mathrm{m}$ 를 사용해야 한다. 민감도 분석 결과 단층 활성화는 수평응력과 수직응력의 비 $\left(\sigma_{H} / \sigma_{v}\right)$ 에 가장 민감한 것으로 나타났으며, 앞서 제시 된 결과 $\left(\sigma_{H} / \sigma_{v}=0.7\right.$ 가정 $)$ 와 비교했을 때 응력비를 0.6 으로 가정하면 폭 $2,000 \mathrm{~m}$ 영역에서 평균 $0.85 \mathrm{~m}$ 의 미 끄러짐이 발생하여 $M_{w} 4.5$ 크기의 지진활동이 발생할 것으로 추정되었다.

\section{3 단층 활성화 시 $\mathrm{CO}_{2}$ 누출 모델링}

Cappa \& Rutqvist(2011b)는 TOUGH-FLAC ${ }^{3 \mathrm{D}}$ 을 이 용하여 Fig. 16(a)와 같이 두께 $10 \mathrm{~m}$ 의 단층이 있는 지 반조건을 모사하고 덮개암과 저류층은 탄성모델로, 단 층은 Mohr-Coulomb 모델로 구성하였다. 그리고 역시 주입률 630.72 tons $/ \mathrm{m} / \mathrm{year}$ 로 일정하게 $\mathrm{CO}_{2}$ 가 주입되 는 과정을 모사하였으며, 그 결과 저류층 내에 존재하
는 단층에서 응력 변화와 변위가 발생하는 것을 확인하 였다. 이와 더불어 Chin et al.(2000)이 제안한 체적변 형률과 유체투과도의 상관관계(식 (17) 및 (18))를 적용 하여 단층 활성화로 인한 유체투과도 증가 효과가 반영 될 수 있도록 하였다.

$$
\begin{aligned}
& \phi=1-\left(1-\phi_{i}\right) e^{-\epsilon_{v}} \\
& k=k_{i}\left(\frac{\phi}{\phi_{i}}\right)^{n}
\end{aligned}
$$

여기서 $\phi$ 및 $\phi_{i}$ 는 각각 현재 및 초기 간극비, $\epsilon_{v}$ 는 체적변형률, $k$ 및 $k_{i}$ 는 각각 현재 및 초기 유체투과도 이다. $n$ 값은 단층의 유체투과도가 대략 10-100 배 사 이에서 증가되도록 15 를 적용하였다. 검토 결과 주입 후 2년 경과 시에는 Fig. 16(b)의 회색 영역까지, 15 년

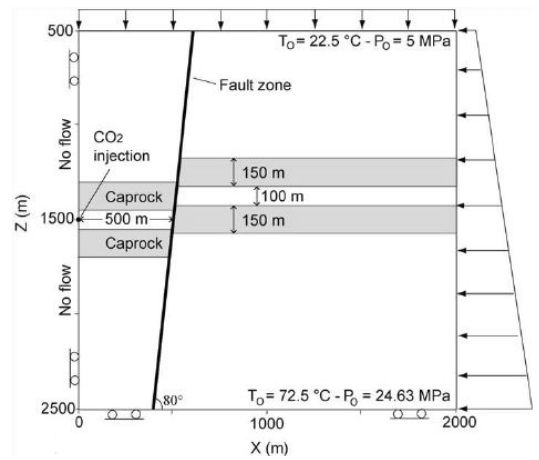

(a) Model geometry
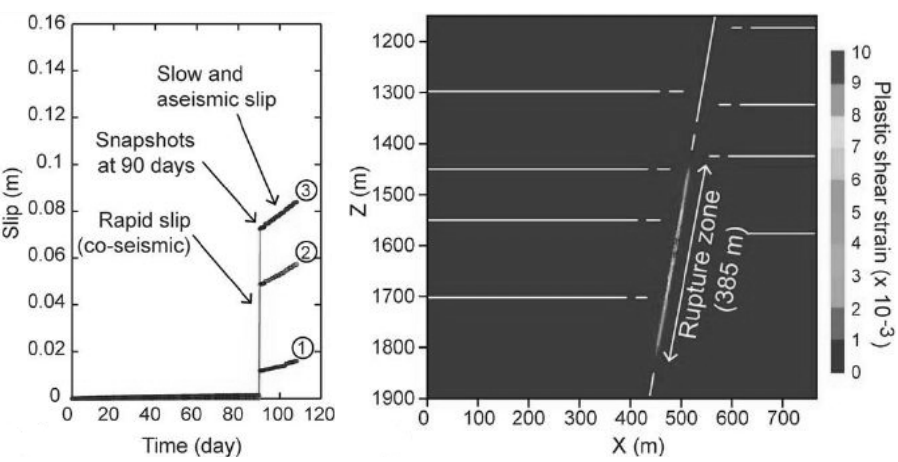

(b) Fault slip and plastic shear strain

Fig. 15. Behavior of the fault governed by a plastic shear strain-weakening friction law (Cappa \& Rutqvist, 2011a)

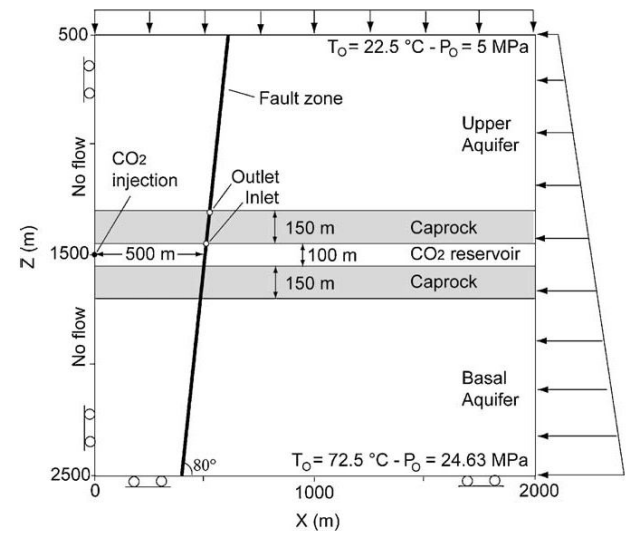

(a) Model geometry

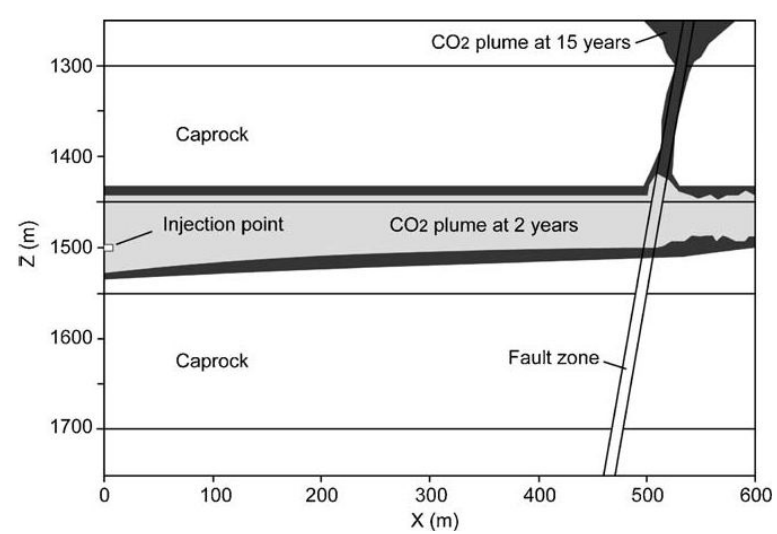

(b) Simulated evolution of $\mathrm{CO}_{2}$-rich phase

Fig. 16. $\mathrm{CO}_{2}$ spread caused by fault instability and permeability change (Cappa \& Rutqvist, 2011b) 


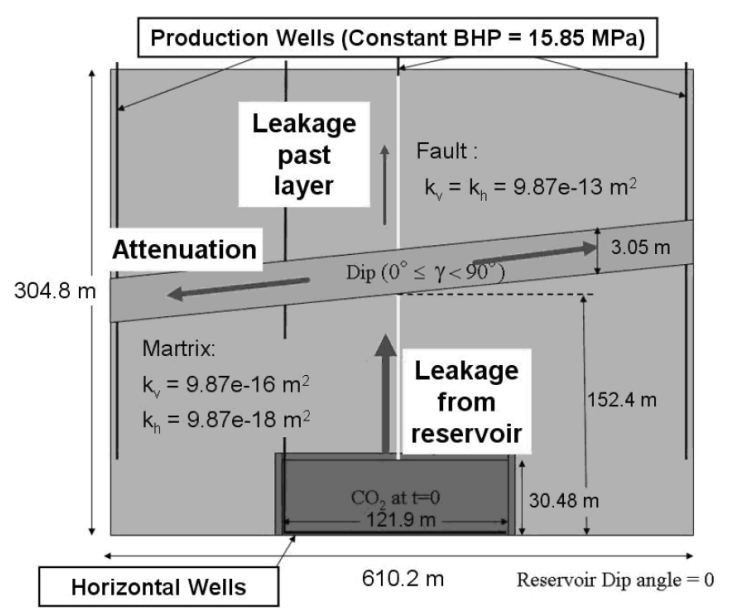

(a) Schematic description of $2 \mathrm{D}$ model

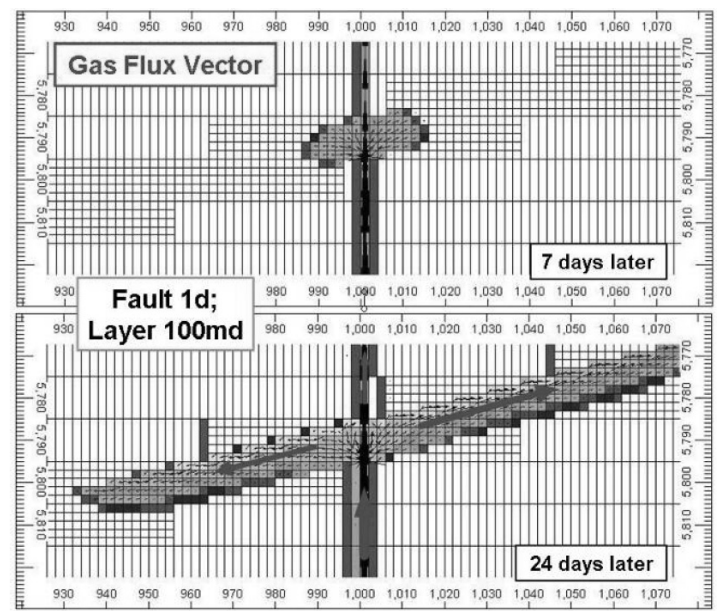

(b) Gas flux vector distribution

Fig. 17. Leakage through fault of $\mathrm{CO}_{2}$ stored in an aquifer (Chang et al, 2008)

경과 시에는 흑색 영역까지 확산되는 것으로 나타났으 며, 유체투과도 증가를 고려했을 때 그렇지 않은 경우 보다 $\mathrm{CO}_{2}$ 누출률이 약 $13 \%$ 증가하였다. 하지만 누출량 은 15 년 동안 주입된 양의 약 $1 \%$ 정도인 것으로 평가 되어 전체적인 양은 많지 않을 것으로 평가되었다.

Chang et al.(2008)은 Fig. 17(a)와 같이 지중저장된 $\mathrm{CO}_{2}$ 가 단층을 통해 누출되는 상황에서 유체가 침투할 수 있는 얇은 지층을 만났을 때 $\mathrm{CO}_{2}$ 가 확산되는 과정을 모델링하고 지층의 유체투과도, 두께, 경사 등이 미치는 영향을 검토하였다. 시뮬레이션 결과 지층의 유체투과 도와 $\mathrm{CO}_{2}$ 의 누출율은 비례관계를 보인 반면 지층의 두 께는 영향을 주지 않았다. 그리고 지층이 기울어져 있 는 경우에는 수평일 때와 다른 양상을 보였으며 부력에 의해 $\mathrm{CO}_{2}$ 가 위쪽으로 더 잘 침투되는 현상이 나타났다 (Fig. 17(b)). 또한 아래쪽으로 기울어진 지층에는 상대 적으로 염수가 많이 침투함으로써 $\mathrm{CO}_{2}$ 의 상향 침투가 더 증가되는 것으로 나타났다.

\section{5. 맺음말}

$\mathrm{CO}_{2}$ 를 지중저장하는 과정에서 상당한 규모의 지진활동 이 감지된 사례는 현재까지 보고되지 않았으나(Rutqvist, 2012) 지중 주입된 다른 종류의 유체 또는 자연 생성되 어 응집되어 있던 $\mathrm{CO}_{2}$ 가 원인이 되어 지진활동이 발생 한 사례들은 다수 확인된 바 있다. 이와 같이 유체압력 의 증가로 인한 단층 활성화는 저장영역의 기밀성 유지 에 중대한 영향을 미치며 상황에 따라 저장기능의 회복 문제 또는 저장중인 $\mathrm{CO}_{2}$ 의 처리 문제 등으로 확대될 수
있다. 따라서 면밀한 현지조사를 통해 현지응력의 크기 와 방향, 유체압력 분포, 단층 분포 등에 대한 불확실성 을 최대한 줄여야 하며, 이를 토대로 부지 선정 또는 주 입압력 결정 단계에서 보다 정확한 모델링을 수행하여 저장영역 내 단층의 안정성 및 $\mathrm{CO}_{2}$ 누출 가능성에 대해 평가하여야 한다. 본 연구에서는 $\mathrm{CO}_{2}$ 의 지중 주입 시 단층 활성화와 관련된 내용들을 사례 중심으로 살펴봄 으로써 최근 연구 동향에 대한 정보를 제공하고자 하였 으며, 단층 안정성 평가 방법 전반을 개관하였다. 하지 만 제한된 현지조사로 인해 저장영역 내 단층 활성화 가능성은 항상 존재하므로 주입 중 모니터링 역시 핵심 요소가 된다. 본문에 제시된 연구 사례 및 해석 방법은 유체압력 변화 감지 등 모니터링 기법 개발과 모니터링 위치 선정 과정에서도 활용될 수 있다.

\section{사 사}

이 논문은 2012년도 정부(교육과학기술부)의 재원으 로 (재)한국이산화탄소포집및처리연구개발센터의 지원 을 받아 수행된 연구임(No. 2012-0008916).

\section{참고문헌}

1. Barton, C.A., M.D. Zoback and K.L. Burns, 1988, In-situ stress orientation and magnitude at the Fenton geothermal site, New Mexico, determined from wellbore breakouts, Geophys. Res. Lett. 15, 467-470.

2. Byerlee, J., 1978, Friction of rocks, Pageoph 116, 615-626.

3. Cappa, F., J. Rutqvist and K. Yamamoto, 2009, Modeling 
crustal deformation and rupture processes related to upwelling of deep $\mathrm{CO}_{2}$-rich fluids during the 1965-1967 Matsushiro earthquake swarm in Japan, J. Geophys. Res. 114, B10304.

4. Cappa, F. and J. Rutqvist, 2011a, Impact of $\mathrm{CO}_{2}$ geological sequestration on the nucleation of earthquake, Geophys. Res. Lett. 38, L17313.

5. Cappa, F. and J. Rutqvist, 2011b, Modeling of coupled deformation and permeability evolution during fault reactivation induced by deep underground injection of $\mathrm{CO}_{2}$, Int. J. Greenhouse Gas Control 5, 336-346.

6. Celia, M.A. and J.M. Nordbotten, 2011, How simple can we make models for $\mathrm{CO}_{2}$ injection, migration, and leakage? (GHGT-10), Energy Procedia 4, 3857-3864.

7. Chae, K.S., S.P. Lee, S.W. Yoon and T. Matsuoka, 2010, Trends of underground $\mathrm{CO}_{2}$ storage technology for the large scale reduction of GHG, Tunnel \& Underground Space 20.5, 309-317 (in Korean).

8. Chang, K.W., S.E. Minkoff and S.L. Bryant, 2008, Modeling leakage through faults of $\mathrm{CO}_{2}$ stored in an aquifer, Proceedings of SPE annual technical conference and exhibition, SPE 115929.

9. Chiaramonte, L., M.D. Zoback, J. Friedmann and V. Stamp, 2008, Seal integrity and feasibility of $\mathrm{CO}_{2}$ sequestration in Teapot Dome EOR pilot: gemechanical site characterization, Environ. Geol. 54, 1667-1675.

10. Chin, L.Y., R. Raghavan and L.K. Thomas, 2000, Fully coupled geomechanics and fluid-flow analysis of wells with stress-dependent permeability, SPE Journal 5(1), 32-45.

11. Deichmann, N. and D. Giardini, 2009, Earthquakes induced by the stimulation of an enhanced geothermal system below Basel (Switzerland), Seismol. Res. Lett. 80, 784-798.

12. EPA, 2010, Underground injection and seismic activity, http:/water.epa.gov/type/groundwater/uic/class6/upload/ uicundergroundinjectionandseismicactivitydec2010.pdf (accessed November 26, 2012).

13. EPA, 2011, Underground injection control (UIC) program class VI well site characterization guidance for owners and operators, http://water.epa.gov/type/ groundwater/uic/ class6/upload/GS_site_Char_Guidance_DRAFT_FINAL_ 031611.pdf (accessed November 26, 2012).

14. Gaarenstroom, L., R.A.J. Tromp, M.C. Jong and A.M. Brandenburg, 1993, Overpressures in the central North Sea: Implications for trap integrity and drilling safety, In: J.R. Parker (ed.), Petroleum geology of northwest Europe: 4th Conference, pp. 1305-1313.

15. Giammanco, S., M. Palano, A. Scaltrito, L. Scarfi and F. Sortino, 2008, Possible role of fluid overpressure in the generation of earthquake swarms in active tectonic areas: The case of the Peloritani Mts. (Sicily, Italy), J. Volcanol. Geotherm. Res. 178, 795-806.

16. Kanamori, H. and E.E. Brodsky, 2004, The physics of earthquakes, Rep. Prog. Phys. 67, 1429-1496.

17. Kim, H.M., E.S. Park, J.H. Synn and Y.C. Park, 2008, Greenhouse gas $\left(\mathrm{CO}_{2}\right)$ geological sequestration and geomechanical technology component, Tunnel \& Underground Space 18.3, 175-184 (in Korean).

18. Jaeger, J.C. and N.G.W. Cook, 1979, Fundamental of rock mechanics - Third edition, Chapman \& Hall, New York.

19. Lucier, A., M. Zoback, N. Gupta and T.S. Ramakrishnan, 2006, Geomechanical aspects of $\mathrm{CO}_{2}$ sequestration in a deep saline reservoir in the Ohio River Valley region, Environ. Geosci. 13, 85-103.

20. Mendes, R.A., A.M. Costa, L.C. Sousa Jr. and L.C. Pereira, 2010, Risks and mitigation problems in a $\mathrm{CO}_{2}$ injection project for a petroleum onshore field in Brazil, In: Proceedings of 44th U.S. rock mechanics symposium and 5th U.S.-Canada rock mechanics symposium, Salt Lake City, Utah, U.S.A., pp. 1506-1515.

21. Miller, S.A., C. Collettini, L. Chiaraluce, M. Cocco, M. Barchi and B.J.P. Kaus, 2004, Aftershocks driven by a high-pressure $\mathrm{CO}_{2}$ source at depth, Nature 427, 724-727.

22. Nabighian, M.N., V.J.S. Grauch, R.O. Hansen, T.R. LaFehr, Y. Li, J.W. Peirce, J.D. Phillips and M.E. Ruder, 2005, The historical development of the magnetic method in exploration, Geophysics 70(6), 33ND-61ND.

23. NETL, 2011, Best practice for: Risk analysis and simulation for geologic storage of $\mathrm{CO}_{2}$, DOE/NETL2011/1459, http://www.netl.doe.gov/technologies/ carbon_seq/ refshelf/BPM_RiskAnalysisSimulation.pdf (accessed November 21, 2012).

24. Nicholson, C. and R.L. Wesson, 1990, Earthquake hazard associated with deep well injection: a report to the U.S. Environmental Protection Agency, 86 p.

25. Ouellet, A., T. Berard, J. Desroches, P. Frykman, P. Welsh, J. Minton, Y. Pamukcu, S. Hunter and C. SchmidtHattenberger, 2011, Reservoir geomechanics for assessing containment in $\mathrm{CO}_{2}$ storage: a case study at Ketzin, Germany, Energy Procedia 4, 3298-3305.

26. Orange, A.S., 1992, Electrical methods, In: D. MortonThomson and A.M. Woods (eds.), Development geology reference manual, AAPG methods exploration series No.10, Tulsa, Oklahoma, pp. 417-419.

27. Park, E.S., H. Kim, D.S. Cheon and H.S. Choi, 2012, Rock engineering issues in $\mathrm{CO}_{2}$ geologic storage, Proceedings of Symposium of Korean Society of Mineral and Energy Resources Engineers (CCS special session), 84-96 (in Korean).

28. Rutqvist, J., 2012, The geomechanics of $\mathrm{CO}_{2}$ storage in deep sedimentary formations, Geotech. Geol. Eng. 30, 525-551.

29. Segall, P. and S.D. Fitzgerald, 1998, A note on induced stress changes in hydrocarbon and geothermal reservoirs, Tectonophysics 289, 117-128.

30. Shimamoto, T. and J.M. Logan, 1981, Effects of simulated clay gouges on the sliding behavior of Tennessee sandstone, Tectonophysics 75, 243-255.

31. Sminchak, J. and N. Gupta, 2003, Aspects of induced seismic activity and deep-well sequestration of carbon dioxide, Environ. Geosci. 10, 81-89.

32. Streit, J.E. and R.R. Hillis, 2004, Estimating fault stability 
and sustainable fluid pressures for underground storage of $\mathrm{CO}_{2}$ in porous rock, Energy 29, 1445-1456.

33. Vidal-Gilbert, S., E. Tenthorey, D. Dewhurst, J. EnnisKing, P.V. Ruth and R. Hillis, 2010, Geomechanical analysis of the Naylor Field, Otway Basin, Australia: implications for $\mathrm{CO}_{2}$ injection and storage, Int. J. Greenhouse Gas Control 4, 827-839.

34. Wiprut, D. and M.D. Zoback, 2002, Fault reactivation, leakage potential, and hydrocarbon column heights in the northern North Sea, In: A.G. Koestler and R. Hunsdale (eds.), Hydrocarbon seal quantification, NPF Special Publication 11, Elsevier, Amsterdam, pp. 203-219.
35. Zoback, M.D. and H. Harjes, 1997, Injection-induced earthquakes and crustal stress at $9 \mathrm{~km}$ depth at the KTB deep drilling site, Germany, J. Geophys. Res. 102, 18477-18491.

36. Zoback, M.D., C.A. Barton, M. Brudy, D.A. Castillo, T. Finkbeiner, B.R. Grollimund, D.B. Moos, P. Peska, C.D. Ward and D.J. Wiprut, 2003, Determination of stress orientation and magnitude in deep wells, Int. J. Rock Mech. Min. Sci. 40, 1049-1076.

37. Zoback, M.D. and S.M. Gorelick, 2012, Earthquake triggering and large-scale geologic storage of carbon dioxide, PNAS 109(26), 10164-10168.

\section{김 현 우}

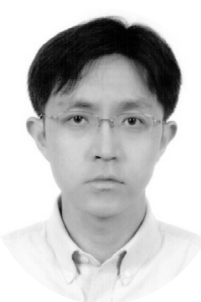

1997년 서울대학교 공과대학 자원공학 과 공학사

1999년 서울대학교 대학원 자원공학과 공학석사

2012년 서울대학교 대학원 지구환경시 스템공학부 공학박사

Tel: $042-868-3243$

E-mail: hyunwoo.kim@kigam.re.kr 현재 한국지질자원연구원 지구환경연 구본부 박사후연수

\section{최 병 희}

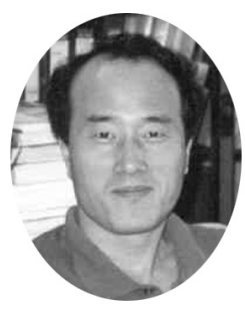

1988년 서울대학교 공과대학 자원공학 과 공학사

2002년 전남대학교 대학원 자원공학과 공학석사

2005년 전남대학교 대학원 지구시스템 공학과 공학박사

Tel: 042-868-3237

E-amil: bhchoi@kigam.re.kr 현재 한국지질자원연구원 지구환경연 구본부 책임연구원

\section{박 의 섭}

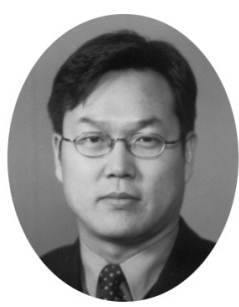

1989년 서울대학교 공과대학 자원공학 과 공학사

1991년 서울대학교 대학원 자원공학과 공학석사

2000년 서울대학교 대학원 자원공학과 공학박사

Tel: 042-868-3098

E-mail: espark@kigam.re.kr

현재 한국지질자원연구원 지구환경연 구본부 책임연구원

\section{천 대 성}

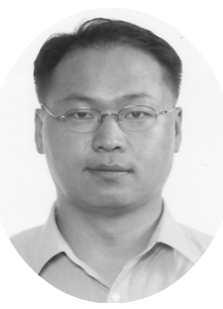

1997년 서울대학교 공과대학 자원공학 과 공학사

1999년 서울대학교 대학원 자원공학과 공학석사

2006년 서울대학교 대학원 지구환경시 스템공학부 공학박사

Tel: 042-868-3248

E-mail: cds@kigam.re.kr 현재 한국지질자원연구원 지구환경연 구본부 선임연구원

\section{최 헌 수}

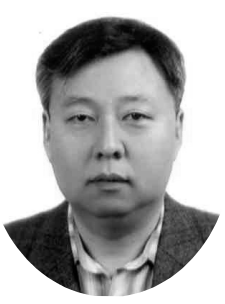

1982년 서울대학교 자연과학대학 지질 학과 이학사

1984년 서울대학교 대학원 지질과학과 이학석사

1994년 서울대학교 대학원 지질과학과 이학박사

Tel: 042-868-3332

E-mail: hunsoo@kigam.re.kr 현재 한국지질자원연구원 석유해저연 구본부 책임연구원 